\title{
MULHERES NAS COMUNIDADES DE SAMBA TRADICIONAL: LIDERANÇA E LUTA RESSIGNIFICADAS
}

Graduada em Relações Públicas pela UNESP (2003), com especialização em Gestão de Projetos Culturais e Organização de Eventos. Pesquisa orientada pelo Prof. Dr. Dennis de Oliveira.

\section{Resumo}

Este artigo discute a atuação da comunidade Samba D'Elas - Herança de Ciata no movimento de retorno ao samba tradicional no contexto da sociedade em rede, cultura do feminino e negro-brasileira.

Palavras-chave: Samba; mulheres; comunidades; rede; negro-brasileira

\section{Abstract}

This article deals about the community "Samba D'Elas - Herança de Ciata” action at the movement of return to traditional samba in the context of net societies, female and black- Brazilian culture.

Keywords: Samba; women; communities; net; Brazilian black

\section{Resumen}

Este artículo discute el funcionamiento de la comunidad Samba D'Elas - Herança de Ciata en el movimiento de vuelta a la samba tradicional en el contexto de la sociedad en red y las culturas en negro-Brasileño y, del femenino.

Palabras clave: Samba; mujeres; comunidades; red; Negro brasileño 


\section{O Samba e as mulheres}

No Brasil, a hibridização cultural dos vários povos africanos foi uma forma de negociação e resistência ao sistema escravista para evitar o aniquilamento total de suas raízes. As "brincadeiras" negras ressignificaram o universo africano resultando em vários tipos de samba: de bumbo, de roda, de terreiro, samba lenço, etc. "Nos quilombos, nos engenhos, nas plantações, nas cidades, havia samba onde estava o negro, como uma inequívoca demonstração de resistência ao imperativo social (escravagista).” (SODRÉ, 1998: p. 12)

Em meados do século XIX a atrofia e posterior abolição da escravatura aliada à crescente chegada de imigrantes europeus tornam o homem negro mão-de-obra excedente. As mulheres negras têm, então, papel decisivo para a sobrevivência de suas famílias: "Com o fim da escravidão, as mulheres assumiram a casa, sustentavam filhos e parceiros na base do biscate e dos tabuleiros de quitutes" (MACEDO, 2007: p. 14)

No fim desse século, no Rio de Janeiro, as tias baianas assumiam a família e abriam suas casas para sambas, choros e candomblés. Na Praça Onze, pólo de sociabilização de negros e mulatos, Tia Ciata cedia sua casa para os primeiros passos do samba urbano. Em São Paulo outras como Tia Olímpia, no Bairro da Barra Funda davam sua colaboração. Surgem então, os ranchos negros, que invadiam o carnaval afirmando a presença negra nos espaços brancos.

Na década de 20 surgem as escolas de samba, a indústria fonográfica e o rádio, formando campo propício para a profissionalização dos homens do samba: "Com base institucional e territorial, artistas negros e mestiços (...) começaram a atuar profissionalmente e a pensar gradativamente em orquestras, emissoras de radiofônicas, gravações fonográficas, aulas de violão para grã-fino etc.” (SODRÉ, 1998: p. 37)

As mulheres são preteridas a este processo, pois a elite branca, fortemente machista, detinha das instituições que promoviam a aceitação dos sambistas em seu universo.

Entre os anos 30 e 50, a classe hegemônica inserida no contexto global do capitalismo ressignifica a miscigenação em ideologia positiva do nacional, forjando relações de poder e profunda violência. O samba, o "malandro", a "mulata" tornamse símbolos nacionais.

A glamorização do malandro carioca, ideologia fortemente presente no universo do samba, oculta problemas sociais como: violência contra mulher, machismo, alcoolismo, pobreza etc. Nesta lógica, mulheres eram submetidas a maus tratos e uma 
responsabilidade familiar solitária, além de ser "porto seguro" para seus maridos, filhos e netos brilhassem na mídia e na avenida.

Algumas mulheres, porém, derrubavam barreiras assumindo papéis de destaque: levando em punho a bandeira de suas escolas, como Dodô da Portela, exaltando as precursoras do samba urbano, como a baiana Anastácia do Nilo ou como a primeira cabrocha, Maria Lata D’Água. Mais tarde brilham na mídia: Dona Ivone Lara, Clementina de Jesus, Clara Nunes etc.

Em 1967, o carnaval paulista é oficializado sob as normas do carnaval carioca, ocorrendo em São Paulo mecanismo similar ao de profissionalização das escolas de samba do Rio de Janeiro. Com o tempo, os mass media se apropriam do carnaval e o transforma em espetáculo, acirrando a disputa entre as escolas. O surgimento de novos atores sociais junto às novas exigências do carnaval interfere na realidade das comunidades, pois “(...) surgem personalidades como a figura do bicheiro, do carnavalesco, ou seja, de pessoas que não compartilhavam os mesmos interesses com os sambistas em relação à escola de samba.” (TROTTA, 2001, p. 05)

As escolas de samba começam a se afastar da comunidade que não se identifica com a "linha de produção" do carnaval-show, o que causa um fluxo de evasão de sambistas que não conseguem ou não querem se inserir na nova lógica, iniciando o movimento de retorno ao samba tradicional.

Outro fator é o privilégio dado pela mídia aos grupos de pagode nos anos 80 e 90. Não discutiremos a qualidade musical destes, pois o objetivo é debater o movimento em contraposição ao carnaval-espetáculo e ao subgênero comercial do samba, elementos geradores do alheamento de relações sociais. Trotta (2001: p. 7) resume a dinâmica:

\footnotetext{
"O aspecto principal desta diferenciação reside no fato de os sambistas não reconhecerem na música desses grupos os mesmos ideais de vida e de sentimentos que estiveram na origem do samba, e aos quais dizem compartilhar, afirmando sua herança."
}

Em São Paulo a busca das relações sociais do samba tradicional resulta nas rodas de samba de comunidade. Alguns exemplos são: Samba da Laje, Samba da Vela, Samba da Ponte, Samba da Tenda, Samba da Paz etc.

Algumas das rodas cantam músicas da "velha-guarda" como homenagem e preservação da memória, outras privilegiam novas composições, o ponto em comum é a atuação dentro da concepção gramsciniana de serem orgânicas às comunidades que se instalam, assim além da busca de retorno ao samba tradicional, adotam uma luta condizente com a realidade encontrada. 
Para a comunidade estudada, a luta não é calcada na realidade territorial e sim de gênero. A bandeira que levantam é a democratização das rodas de samba para a atuação das mulheres de maneira mais ampla, livre e igualitária.

\section{Samba D’Elas - Herança de Ciata}

Neste contexto das comunidades de samba onde há hegemonia masculina, surge a Samba D’Elas - Herança de Ciata.

Em março de 2008, a comunidade Samba da Vela realizou uma roda de samba feminina em homenagem ao dia das mulheres, que foi composta por Ana Elisa, Cida, Zanza, Elisa, Thais, Dígena, Camila e Gilda. Na época essas mulheres já atuavam isoladamente em comunidades específicas.

As irmãs Ana Elisa e Cida da zona sul de São Paulo eram intérpretes e compositoras do Samba da Vela há quatro anos. Na zona leste outras irmãs, Zanza e Elisa, eram musicistas e parte do corpo executivo do Samba da Tenda há três anos. Essas mulheres, que continuam nos projetos referidos formariam a diretoria da comunidade Samba D'Elas.

Em 2000 Zanza, Elisa e outras fundam a comunidade Espaço de Samba Feminino, nascida no mesmo espaço do Samba da Vela, mas não dura muito.

Dígena, Camila, Gilda participavam esporadicamente de rodas em comunidades de samba.

Como o Samba da Vela ocorre às segundas-feiras, a roda realizou-se dia 10, data mais próxima ao dia das mulheres. A sinergia foi imediata, como narra Zanza "rolou uma simpatia logo de início, uma energia" e Ana Elisa,"o santo bateu".

No sábado, da mesma semana, tocaram na comunidade Rua do Samba Paulista, no domingo, Zanza e Elisa receberam as demais no Samba da Tenda coroando uma semana de homenagem às mulheres em comunidades de samba e iniciando o processo de formação da Samba D’Elas.

Uma reunião definiu as diretrizes da comunidade que seguiria o movimento de retorno ao samba tradicional pensando a mulher nesse contexto.

A diretoria feminina conduziria as atividades, a roda de samba teria maioria de mulheres, mas também seria aberta a homens. A roda começa itinerante, visitando comunidades, espaços de samba e as próprias casas das participantes. 
Em de julho de 2008, fecham parceria com o Raízes Bar, localizado na Penha, onde a roda passa a ocorrer quinzenalmente. O bar fecha em julho de 2009 e a roda é transferida para o Quintal Bar, no mesmo bairro.

Hoje a roda fixa é composta por Ana Elisa, Cida, Bia, Zanza, Elisa, Sandrinha Lima, Tais, Marcos Morais, Serginho do Sete, Batata e Beijoca.

\section{Diálogos Circulares}

Para entendermos a atuação da comunidade Samba D’Elas Herança de Ciata no movimento de retorno ao samba tradicional, apresentaremos os conceitos norteadores de nossa análise que por suas características e ordenação dialéticas, chamaremos de diálogos circulares.

\section{Sociedades em Rede}

A primeira característica de dimensão, dos diálogos circulares, é a sociedade em rede, lógica para que caminham as relações no mundo hoje. Para Castells, as novas tecnologias de informação impulsionam o processo, permitindo que redes atinjam níveis globais. Os atributos das organizações em rede são segundo León (2001: p.5): flexibilidade, horizontalidade, interconexão, articulação, multiplicação e intercâmbio.

Os empresários e líderes políticos já pensam na reordenação de estruturas hierarquizadas em modelos de gestão e trabalho horizontais, no entanto, a recriação das velhas instituições sob o pensamento individualista, explorador, desigual e desumano, não altera tais pilares da sociedade neoliberal.

\footnotetext{
"Cambiar de arriba abajo las reglas sin destruir la organización se ha convertido en una posibilidad (...) Sin embargo, debemos evitar un juicio de valor unido a este rasgo tecnológico. Porque la flexibilidad puede ser una fuerza liberadora, pero también una tendencia represiva si quienes reescriben las leyes son siempre los mismos poderes" (CASTELLS apud LÉON, 2001: p. 01).
}

Assim é urgente pensarmos o empoderamento das redes e novas tecnologias pelas classes subalternas em favor de suas lutas.

No final do século XX surgem movimentos de oposição ao neoliberalismo questionando a vida e as relações mercantilizadas, dividindo-se segundo Hardt (2003: p. 342) em:

- Antiglobalização (pró-soberania): agem em oposição, mas ainda intrinsecamente ao próprio neoliberalismo, pois “(...) trabalha-se para reforçar a soberania do estado-nação como barreira defensiva contra o controle do 
capital estrangeiro e global";

- Globalização democrática (não soberana): embora não ofereçam uma proposta formal, desenham uma nova conjuntura por redes.

No entanto, as contradições não dividem em lados opostos os movimentos em rede, pois se conectam por suas similaridade de valores.

\footnotetext{
"Si se tratara de establecer un denominador común, lo que resalta en esta amplia gama de acepciones es un rechazo a posiciones hegemonistas y el reconocimiento de los límites del accionar específico de cada organización o entidad y, por lo tanto, la necesidad de asociarse con otras afines, bajo valores compartidos, para potenciar su incidencia y alcance." (Léon 2001: p. 04)
}

A ideologia humanizada é o maior ponto conector entre os movimentos subalternos (e em redes), aqui a interdependência propulsiona a autonomia comum (por uma globalização alternativa) e individual (em suas lutas específicas).

A nova configuração de atuação política da sociedade civil preserva as diversidades culturais, pois tende à circularidade, conceito que transpassa as culturas do feminino e negro-barsileira.

\section{Cultura do Feminino}

O conceito de Manzini-Couvre, cultura do feminino, tem atributos que marcam a origem da cidadania em construção, emergente das brechas da alta-modernidade ${ }^{1}$, como uma nova forma de ação política pelas mãos do sujeito em constituição.

Para a autora, a crise do Estado de Bem Estar Social fragmenta o antigo movimento operário em novos movimentos sociais, indicando "nichos fragmentários para a emancipação" (MANZINI-COUVRE, 1996, p.11), articulados por sujeitos da nova cidadania organizada em rede.

O sujeito em constituição passa por um processo árduo de autoconhecimento, buscando valores presentes em sua alma e a quebra da autoimagem no conturbado cenário da alta-modernidade. Esta, regida pelo binômio trabalho-consumo, implica em valores da cultura do masculino como força, individualismo, consumo, competição, etc.

Aqueles ainda presos aos valores da alta-modernidade assumem a "cidadania do status quo" e adotam atitude passiva e consumista centrada no ser. A classe hegemônica faz uso dos mass media para afirmação de sua ideologia, instigando a aceitação das ações do Estado. 
A emancipação do sujeito pede uma trabalhosa quebra de paradigmas e o entendimento da identidade em movimento, centrada no sentir. Isso exige um novo fluxo de alteridade ocorrendo para aqueles que se aventuram na quebra da identidade como categoria fixa, concebendo a possibilidade de identidades que dialogam entre si para a formação de um só sujeito que atua sob os valores da cultura do feminino:

\footnotetext{
“(...) solidariedade, defesa da vida e da qualidade de vida, olhar antitrágico e criador, "astúcia", pressa-vagarosa, paciência e persitência sherazadeana, amizade, "agoridade", movimento com rumo ético, indeterminismo, competência a favor dos necessitados (generosidade), altruísmo (amor), capacidade de lidar com o sombrio e luminoso da alma, no equilíbrio, sem cair no abismo, o brincar, o estetizar e o criar sentido da existência." (MANZINI-COUVRE, 1996: p. 08).
}

Baseada nesses valores a rede de sujeitos em constituição articula novas formas de atuação política (humana e horizontal), onde cada sujeito (ou grupo de sujeitos) tem suas buscas particulares em diálogo com as buscas coletivas.

\section{Cultura Negro-Brasileira e Matrifocalidade}

Um dos pilares da cultura ocidental, as verdades universais, impostas às classes subalternas em ações ideológicas, políticas ou de força, resultam no valor vital dessa cultura, o dualismo. Este fragmenta em pólos opostos o entendimento do universo, das relações, dos sentimentos e de qualquer significado cultural.

Já nas culturas africanas não há verdade a ser "iluminada" e os elementos são concebidos como pontos constituintes e comunicantes de um mesmo sistema. "Para os nagôs, a existência transcorre em dois planos: o aiê (a Terra, o visível) e o orum (o espaço invisível). São planos distintos, mas interpenetrados" (SODRÉ, 2005, p. 96).

Na cultura negra, o principal mecanismo de ordenação é o jogo, que dinamiza a energia vital por meio de trocas. As relações advêm em forma de duelo leal, pois os participantes (não oponentes) obedecem a um conjunto de regras que privilegia o jogo e não a vitória unilateral: "Uma vez no interior do jogo, deixa-se de ser sujeito de troca, para se tornar parceiro, membro paritário, de uma dinâmica (agonística, mas não contraditória) pontuada por obrigações a serem cumpridas" (SODRÉ, 2005, p. 109).

As relações de poder são mais horizontais e dialéticas, pois o poder é diluído no jogo, como vemos no candomblé:

\footnotetext{
“(...) homens e princípios cósmicos (orixás) encantam-se, atraem-se, são parceiros de um jogo. O poder dos orixás não exerce por hipotaxe (subordinação), mas por parataxe (coordenação), sem os pressupostos desse absoluto de força implicado no Ocidente pela verdade (primeiro, de Deus; depois, do Homem e da História)." (SODRÉ, 2005: p. 123).
} 
Por meio de brechas da cultura ocidental-hegemônica, a cultura negro-brasileira ressignifica elementos africanos como jogo, coletivismo, ritual, duelo etc, que persistem como religião (candomblé e umbanda), capoeira, batuques (mais tarde o samba), organização familiar (matrifocal) etc. Para compreensão do nosso estudo de caso nos focaremos na matrifocalidade.

A sociedade brasileira é impregnada de machismo, que tem raízes no Brasil colonial, pois os portugueses "coisificavam" as índias e negras em objeto de prazer ou trabalho, enquanto submetiam as mulheres brancas à ideologia do Marianismo, que balizada por valores católicos "santificava" a mulher colocando-a numa posição frágil e sem autonomia. O arquétipo do "(...) modelo de Maria, idolatra a mulher mártir que se auto-sacrifica, que é submissa aos homens, que é uma boa mãe e esposa" (NEUHOUSER apud DE SOUZA, 2000, p. 06).

A mulher negra resiste a essa opressão ressignificando uma prática de vários povos da África, o comércio como atividade feminina; que permitia a matrifocalidade econômico-familiar e respectivamente a troca de bens simbólicos neste espaço social (mercado).

No Brasil, segundo Verger, praticando o comérico "as ganhadeiras-mulheres (ou forras)" exercitavam a matrifocalidade remontando simbolicamente a importância que tinham em seus povos e organizações familiares africanas, promovendo considerável grau de emancipação se comparadas à situação do homem negro, pois os dividendos gerados eram possibilidade real para compra de suas alforrias, assim a organização familiar negro-brasileira nasce matrifocal.

Na cultura negro-brasileira a mulher é protagonista de sua história e liberdade assumindo a família, a religião e a comunidade, porém o empoderamento e ampliação da condição de líder é diferente da lógica do sistema hegemônico a que se opõe. Para a categoria de indivíduos triplamente subalternizados (negras, pobre e mulher) o poder é edificado de forma humanizada e coletiva.

\section{Samba D’Elas - Herança de Ciata: poder feminino ressignificado}

Para a compreensão de nosso objeto de estudo, analisamos a comunidade Samba D'Elas, usando como metodologia: análise entrevistas abertas, observação paticipante e pesquisa bibliográfrica.

As comunidades de samba são parte dos movimentos por uma globalização democrática, pois se opõe a mercantilização das relações humanas neste universo. A comunidade estudada atua neste sentido e pela igualdade de gênero, na lógica de redes. Observamos características dessa ordenação: No intercâmbio de sambistas de 
diferentes comunidades, o que resulta em parcerias e projetos e gera a troca de bens simbólicos fincados nos códigos de valores das comunidades.

$\mathrm{Na}$ articulação entre as comunidades para a fortificação e multiplicação dos objetivos do movimento de retorno de samba tradicional e da própria comunidade (abrir espaço às mulheres no samba). Em busca desses objetivos apropriam-se de mídias e espaços hegemônicos atentando para não descaracterizar o movimento do samba de raiz, como explica Cida:

\begin{abstract}
"A gente não tem a intenção de descaracterizar o trabalho que a gente faz. Lógico que parte do que a gente faz, é apresentar o que a gente compõe, o que a gente cria, mas é também valorizar, reproduzir, mostras coisas boas e importantes que já aconteceram que foram gravadas (...), a gente tem a pretensão de fazer o que a gente faz ser conhecido. Então se a mídia é uma forma, uma ferramenta dessa percepção, eu acho natural que a gente vise sim, determinados espaços e espaços culturais. A gente quer estar sim nesse circuito de SESCs, nesses circuitos de Casas de Cultura, nesses trabalhos assistenciais, perto da comunidade (...). O objetivo não é a segregação, mas é a ampliação de espaço e manutenção dessas coisas que são positivas, acho que fica dentro do contexto do samba."
\end{abstract}

A comunidade age com flexibilidade ao apropriar-se de meios de comunicação que em princípio mercantilizaram as relações do samba. Sem nenhuma ingenuidade desconstroem essa dinâmica e utilizam a mídia como propulsora das redes e seus objetivos.

Outro ponto é a horizontalidade de poder, onde decisões são tomadas em conjunto e a superação das desavenças é feita com diálogo sincero e até exaustivo (por refutarem uma hierarquia rígida, atritos transluzem, mas são superados por negociações). Marcos resume:

\footnotetext{
“(...) não interessa se elas são ótimas instrumentistas, ou ótimas cantoras, ou ótimas compositoras nem nada, mas eu acho que elas fazem bem o papel de comunidade. Porque o que eu entendo de comunidade é todo mundo fritar o peixe na mesma banha, como o sambista diz e não ter o lance da hipocrisia. Elas racham o pau? Racham o pau mesmo, lindo! Mas não fica aquele "disque que não me disque", o que elas têm pra falar cada um fala pra outra e acabou e o samba se fortalece por conta disso, porque não tem hipocrisia".
}

Os atores sociais estudados demonstraram serem sujeitos em constituição atuando na cidadania em construção, pois agem em suas lutas (coletivas e específicas) centrando-se no sentir, demonstrando a presença dos valores do feminino em suas “identidades" em diálogo, seja na atuação nas comunidades, em seus trabalhos, família ou outros âmbitos de suas vidas.

Nas falas notamos características do feminino como: olhar criador, pressa-vagarosa, sinuosidade, paciência e persistência sherazadeana: "Mulher duvida do trabalho de mulher (...). É um pouco dessa cultura, não é habitual, não estão acostumadas 
com esse tipo de coisa, então você vai ter que convencer as pessoas de que é um projeto legal." (Cida, grifos meus).

"Uma das maiores mudanças que a gente fez na Tenda, (...) a gente sugeriu que se parasse de beber
na roda (...) a gente ouviu pra caramba: “A vocês ficaram loucas?"(...) mas aos poucos foram ade-
rindo. (...) Com isso começou a mudar um pouco, começou a ir mais mulheres porque o ambiente
é melhor (...) um público maior e focado, muito familiar." (Zanza, grifos meus).

Vimos o olhar antitrágico, solidariedade, generosidade, defesa da qualidade de vida, quando Sandrinha relata:

“(...) trabalho com o "Proerd", que é uma entidade da polícia militar, que cuida de crianças viciadas, largadas, que ninguém quer mais. É um projeto de bem-estar da criança. A gente pega as crianças da rua e dá todo o suporte pedagógico, dá assistência médica. São viciados, então a gente faz um trabalho de desintoxicação. É duro, mas é gratificante." (grifos meus)

Zanza narra, em seu blog, a homenagem que resultou no Samba D’Elas, mostrando a centralização no sentir:

\footnotetext{
“(...) pisar naquele terreiro depois de uns 5 ou 6 anos sem ir para realmente participar, foi para mim um momento mágico, lembrei de cada alegria que ali tive, das amizades que até hoje tenho, dos momentos de besteirol dos meninos, do macarrão do oliveira, de um monte de prato pra ajudar a lavar, da emoção de ouvir "a comunidade chora", enfim foi bacana demais rever algumas pessoas" (grifos meus)
}

A cultura negro-brasileira que permeia o samba, e demonstra as ressignificações culturais africanas em solo brasileiro, é também mãe das relações das comunidades de samba. A comunidade Herança de Ciata, apresenta elementos de persistência da cultura negra como a conexão dos integrantes às religiões negro-brasileiras e a ligação entre sagrado e profano: "Eu pulava o muro e ia para um terreiro que às quartas feiras rolava samba nesse terreiro (...) os outros dias era um terreiro de umbanda, então tinha toda a ligação" (Marcos Morais).

\footnotetext{
“(...) nos bastidores do samba é que fica o astral. Todo esse negócio da religião que tem no samba no samba é um negócio muito verdadeiro, tem gente que vem tocar, traz um pouco do candomblé, traz um pouco da mesa branca por exemplo." (Marcos Morais).
}

Outra persistência é o caráter ritualístico e de abolição do sentido instrumental, pois o sentido está na própria prática da roda; ela é quinzenal e tem uma música inicial específica e outra de finalização; as meninas vestem uma das peças de roupa na cor rosa e usam uma toalha da mesma cor na mesa.

Verificamos também a visão circular que entende o próprio movimento do pagode (que questionam autenticidade) como elemento do jogo dinamizando a "força vital” do samba. Cida observa: “(...) há pessoas que começam ouvindo pagode e a partir do pagode se apaixonam pelo samba de raiz ou outras vertentes do samba, 
como o samba regional, a escola de samba (...) então o pagode, abre portas nesse sentido hoje".

Notamos ainda a presença do machismo que como discorremos bifurca em marianismo e coisificação da mulher; "No samba tradicional você vai ter ou a mulher 'zuada', demais! 'Zuada' no sentido atual ou depreciada. Porque ou ela é a coitada, tipo Amélia, ou ela é aquela a perdida, a bandida, a safada, entendeu? Ela vem nesse sentido pejorativo", como percebe Cida.

No entanto, a matrifocalidade impulsiona essas mulheres a reinventarem a posição de mulher na sociedade e no samba. As mulheres que conversamos tornamse líderes tanto no movimento de retorno ao samba tradicional, como na luta pela igualdade de atuação nas rodas de samba.

Vimos a matrifocalidade em vários aspectos da vida dos integrantes: na organização familiar, as mulheres que tem filhos (Sandrinha, Cida e Ana) são chefes de família e separadas, nas profissões observamos o posicionamento de liderança e solidariedade como professoras, diretoras de escola ou atuações como a de Sandrinha. Na própria comunidade, Zanza, Cida e Elisa, agregaram a roda seus companheiros, respectivamente: Batata, Marcos e Beijoca.

Estas mulheres caminham para um poder fora da lógica da brutalidade, mas na lógica da solidariedade, sinuosidade e diálogo, características próprias da cultura do feminino e da cultura negro-brasileira, ordenadas por meio de redes, como sintetiza Cida:

“(...) a gente tem que fazer um pouco diferente do que os homens fazem, então a gente ta tentando segregar menos, fazer um trabalho mais em conjunto do que de segregação, do que continuar mantendo as mulheres de um lado e os homens de outro. A gente quer fazer uma coisa que seja mais uniforme. Lógico que isso é um processo, é processual! É um trabalho de formiguinha" (grifos meus).

\section{Considerações finais}

No interior do panorama apresentado é que as culturas subalternas atuam. A visão circular de mundo salta aos olhos, já que as relações dos sujeitos em constituição por uma constante cidadania em construção se desenvolvem em redes. O pensamento hegemônico cai por terra, quando são admitidas brechas de atuação e a matrifocalidade reverte a lógica vigente na construção de uma nova realidade, prioritariamente mais humana por meio das lutas do cotidiano.

Observamos por meio desta pesquisa que a resistência das culturas subalternas está mais presente na sua lógica de organização e atuação que em seu conteúdo 
ou lutas específicas. Esta lógica busca humanizar as relações pautando-se em valores éticos e democráticos.

\section{Referências bibliográficas}

BERNARDO, Teresinha. "O Candomblé e o Poder Feminino" in: "Revistas de Estudos da Religião", São Paulo: PUC/SP, n 2, 2005

DE Souza, E.; Baldwin, J. R; Rosa, F.H. “A construção social dos papéis sexuais femininos”. Psicologia Reflexão e Crítica, 2000.

DIAS, Fernanda de Freitas. "O samba de bumbo em Pirapora: Construção de uma expressão singularmente paulista?" in: "XVII Congresso da Anppom - Associação Nacional de Pesquisa e Pós-Graduação em Música”, São Paulo: Anppom, 2007.

DOZENA, Alessandro. "Os movimentos de samba na cidade de São Paulo: Espaços de resistência e de esperança" in: "XIII Seminario APEC - Asociación de Investigadores y Estudiantes Brasileños en Cataluña", 2008.

LIMA, Luiz Fernando Nascimento de. "O pagode nos anos 80 e 90: centratildade e ambivalência na significação musical” in: Revista Em Pauta, $\mathrm{n}^{\circ} 31$, julho à dezembro, 2007

MACEDO, Gisele . "A Força Feminina do Samba”. Rio de Janeiro: Centro Cultural Cartola, 2007.

MARTINS, Juremir Machado da Silva (org), "Para navegar no século XXI". Porto Alegre: Sulina/Edipucrs, 2000.

MANZINI-COUVRE, Marilou. "No caminho de Hermes e Sherazade - cultura, cidadania e subjetividade". Taubaté: Vogal, 1996.

MORAES, Denis de. "Por uma outra comunicação - mídia, mundialização cultural e poder”. Rio de Janeiro: Record, 2003.

MORIN, Edgar. "Da necessidade de um pensamento complexo" in: MARTINS, Francisco Menezes e SILVA, Juremir Machado da (orgs.). "Para navegar no século 21 ”. Porto Alegre: Sulina/Edipucrs, 1999.

ORTIZ, Renato. "Cultura brasileira e identidade nacional”. São Paulo: Brasiliense, 2006.

RIBEIRO, Darcy. “O povo brasileiro - a formação e o sentido do Brasil”. São Paulo: Companhia das Letras, 1995. 
ROLNIK, Raquel. "Territórios negros nas cidades brasileiras (etniciadade e cidade em São Paulo e Rio de Janeiro)" in: "Cadernos Cândido Mendes - Estudos Afro-Asiáticos", n 17, Rio de Janeiro, 1989.

SODRÉ, Muniz. "A verdade seduzida: por um conceito de cultura no Brasil". Rio de Janeiro: DP\&A Editora, 2005.

."Samba o dono do corpo". Rio de janeiro, Mauad, 1998.

SCHWARCZ, Lilia Katri Moritz ."Complexo de Zé Carioca: Notas sobre uma identidade mestiça e malandra" in: "Revista Brasileira de Ciências Sociais", nº 29, out/1995.

. "Retrato em Branco e Negro". São Paulo, Companhia das Letras, 1987.

TROTTA, Felipe C.; CASTRO, João Paulo M. "A construção da idéia de tradição no samba”. Cadernos do Colóquio, v. 1, p. 62-74, Rio de Janeiro: UNIRIO, 2001.

\section{Webgrafia}

LEÓN, Oswaldo. "Movimientos sociales en la Red", 2001. Disponível em: http: //alainet.org/publica/msred/1P-c2v2.html, acessado em 10/04/09

You Tube. Disponível em: http://www.youtube.com/watch?v=9zTb6yb78Tw SIMIÃO, Elisângela. Blog. Disponível em: http://zanzasimiao.blogspot.com MORAES, Márcia Soman. "Das lavouras de café ao sambódromo". São Paulo: USP, 2007. Disponível em: http://www.usp.br/jorusp/arquivo/2007/jusp790/pag0809.htm Revista Agenda Cultural da Periferia, $\mathrm{n}^{\circ} 21$ e $\mathrm{n}^{\circ}$ 24. São Paulo: Ação Educativa, março de 2009 e junho de 2009. Disponível em: http://www.acaoeducativa.org.br/ agendadaperiferia/edicoes.html.

\section{Notas}

${ }^{1}$ Conceito do autor Giddens utilizado por Manzini Couvre. 
MULHERES NAS COMUNIDADES DE SAMBA TRADICIONAL:

LIDERANÇA E LUTA RESSIGNIFICADAS

ANEXOS

1. Fotografias (apresentação do Samba D’Elas)
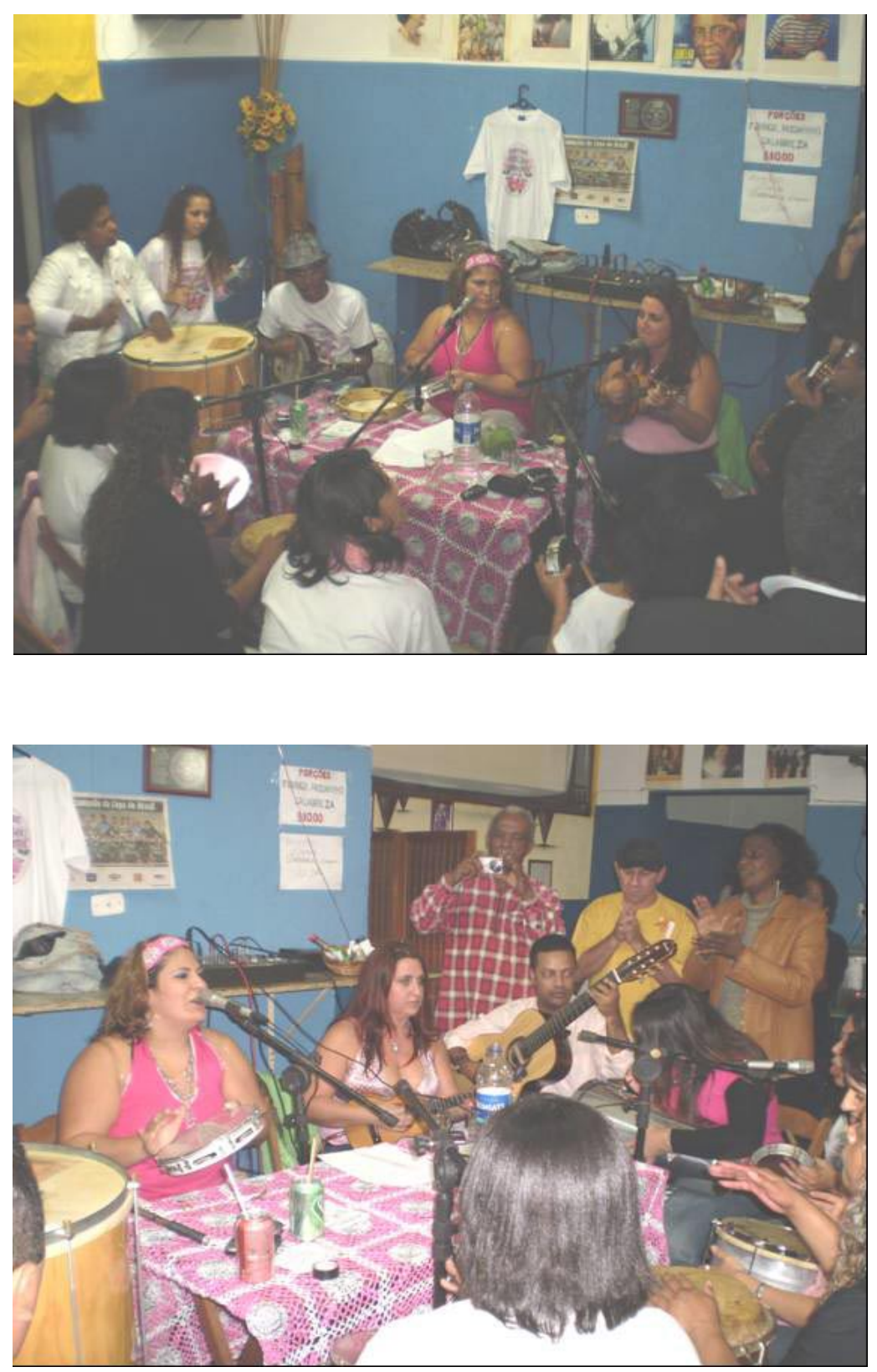
MULHERES NAS COMUNIDADES DE SAMBA TRADICIONAL:

LIDERANÇA E LUTA RESSIGNIFICADAS
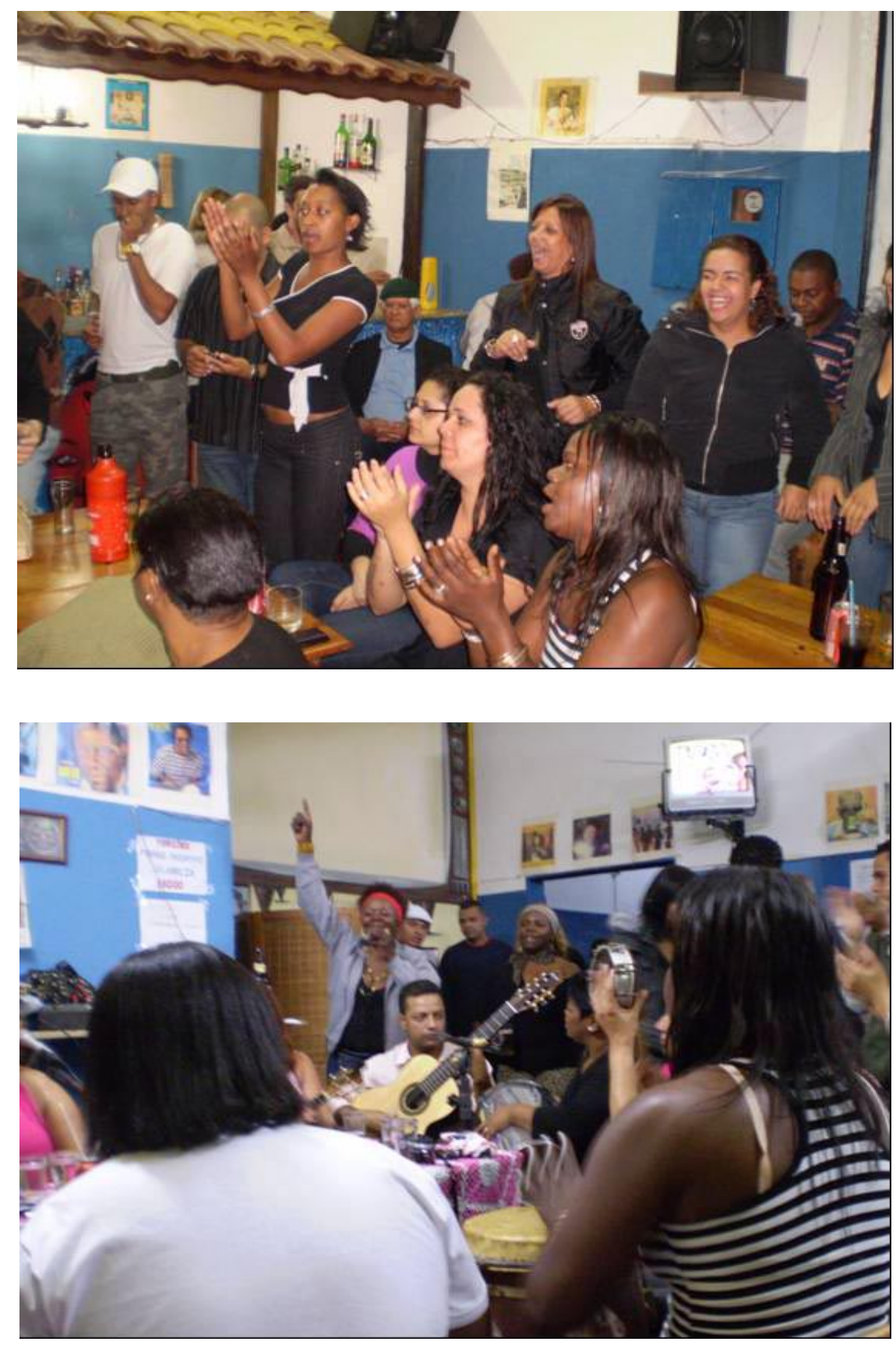

$\overline{\text { EXTRAPRENSA }}$ 
MULHERES NAS COMUNIDADES DE SAMBA TRADICIONAL:

LIDERANÇA E LUTA RESSIGNIFICADAS
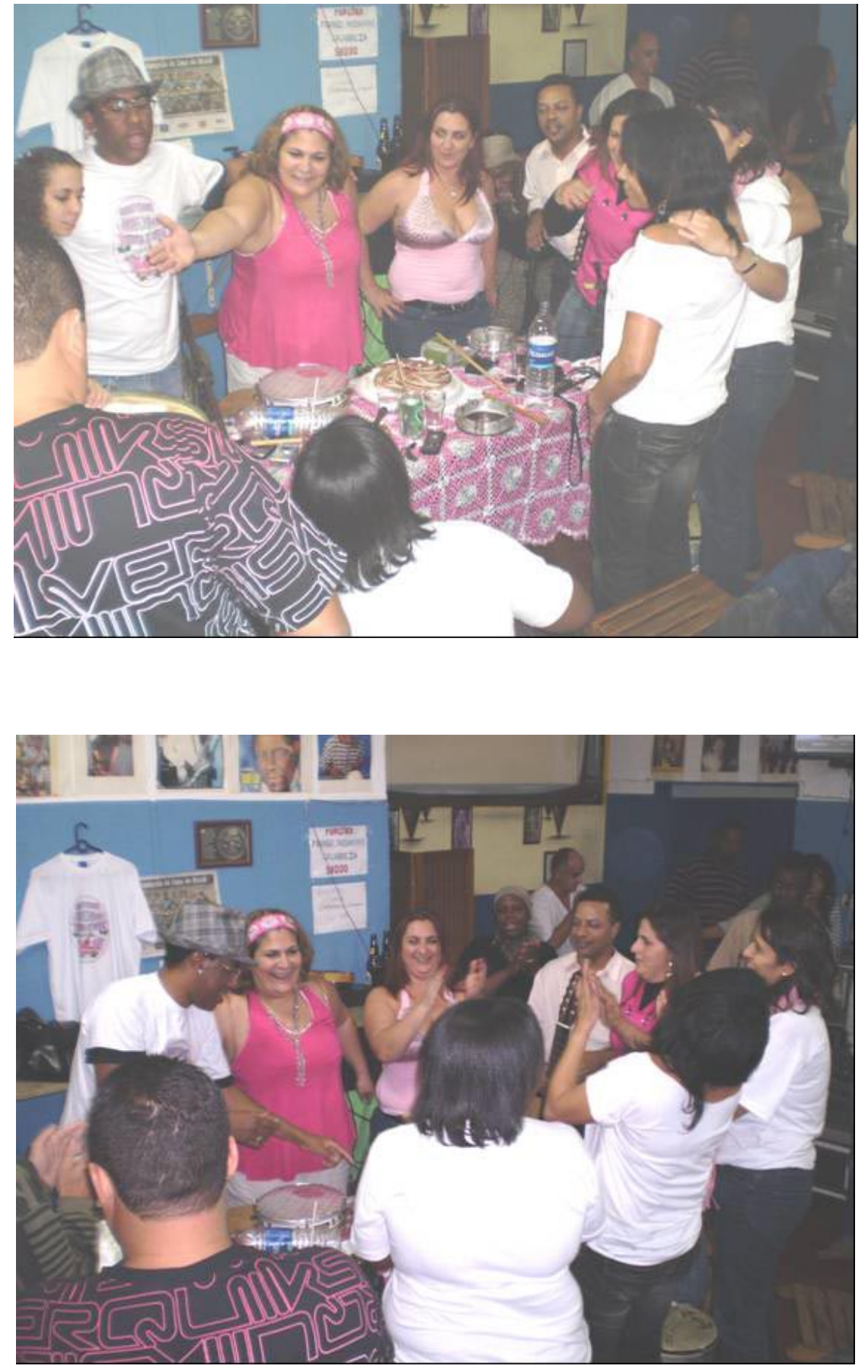

EXTRAPRENSA 


\section{Entrevistas Abertas}

\section{Ana Elisa dos Santos Camargos (Ana Elisa), 45 anos, canta e compõe}

Pergunta: Conte um pouco da história do Sambadelas

Ana Elisa: O "Samba D'elas" a gente criou, pensando num espaço onde a mulher não tenha que pedir licença aos homens pra estar fazendo samba e mostrando seu trabalho, porque as rodas de samba em Sã Paulo, talvez não por maldade, mas por um costume tem as mulheres na sua maioria como pastoras ou como simplesmente dançarinas, como cabrochas.

Então a gente tem que perder esse tipo de coisa, e sair desse conceito, então pra isso a gente criou uma comunidade onde a gente seja a maioria e a gente defina os rumos, onde a gente realmente mande (risos)...

Porque a mulherada, muitas vezes não tem muita voz ativa, por não ter muita participação, então a mulher, apesar da mulherada estar no samba a muito tempo e estar participando a muito tempo, aqui em São Paulo; Aqui em São Paulo, porque eu não conheço as rodas do Rio, as rodas assim esse tipo de roda de samba de comunidade, então nós não como é que funciona, mas aqui em São Paulo, agente sente muito isso, as rodas aqui em São Paulo são muito fechadas nos sentido masculino, os homens normalmente lideram assas rodas.

Então quando eles vêem a mulher participando, a mulher tocando um instrumento ou a mulher compondo, e fazendo parte integrante disso tudo, então as pessoas às vezes até se assustam, falam. Nossa, a mulher tocando! Nossa a mulher compondo! Nossa ela toca pandeiro! É como se fosse a mulher quando começou a dirigir, porque ainda tem pessoas que, pois mais que a mulher dirija, que a mulher faça seu trabalho, ela ainda é encarada como "a mulher no volante", infelizmente...

Pergunta: Conte um pouco sobre a história de sua vida

Ana Elisa: Eu venho de uma família de músicos, meu pai cantava, meu pai foi radialista, apesar de já ter feito todo tipo de coisa, de já ter tido o tipo de profissão.

Ele foi um cara que veio de Minas Gerais, aí veio pra cidade grande, foi pro Rio de Janeiro tal, pra batalhar, mas foi um cara que sempre cantou, que sempre tava com essa música inserida. Então agente cresceu numa família de 5 pessoas, eu, meu pai e minha mãe e mais 2 irmãos, que tem a Aparecida também que faz parte desse Samba D'Elas, desse nosso projeto. 
A gente cresceu uma família musical, então todas às vezes depois das refeições, não tinha aquela de levantar e ir embora, não, a gente sentava lá na mesa e a gente cantava, a gente fazia primeira, segunda, terceira voz... Então meu pai sempre insistia nisso... Fazia o coro...

\section{Pergunta: E já era Samba?}

Resposta: Também, porque meu pai tocava pandeiro, tocava flauta, toca um pouco de violão, então a gente ia na onde dele, então o samba era muito presente, só que o samba era como esse samba hoje, era uma coisa mais... Séria, ou a conduta era diferente, às vezes a gente vê a coisa muito comercial, e o samba antigamente era uma coisa mais familiar mesmo.

A família participava quando a gente ia ao interior de São Paulo, principalmente em Piracicaba, a gente tinha muitos parentes em Piracicaba, então quando a gente ia ver desfiles de escola de samba, participar de carnaval, essas coisas, era uma coisa assim legal, mas familiar, não era essa coisa comercial que se tornou o samba hoje.

Hoje em dia o samba é muito conchavo, muito trato, e eu cresci nesse meio gostoso, de curtir o Samba, o carnaval, era uma coisa gostosa de fazer, era uma coisa gostosa de curtir pelo prazer que isso dava, não por grana, não por nada, mas simplesmente era um prazer e valorizava os cantores mais antigos. A gente ouvia muito Ataulfo Alves, Elizete Cardoso... E cantava e reproduzia essas músicas porque era uma coisa gostosa, era uma coisa legal de se fazer, então não era tão comercial, por isso que muitas vezes a gente aborda alguns temas nas músicas da gente por conta desse comércio que virou o samba.

Pergunta: Você só canta, ou toca e compõe?

Resposta: Eu na realidade fiz um pouco de aula de violão, tive que parar porque casei, dei um tempo, participava e festivais e tudo mais, e aí me dediquei mais a esta parte do lar, mas sempre compondo. Sempre compus, sempre escrevi muita poesia, sempre escrevi muita música; Tanto que a primeira música que eu apresentei no Samba da Vela, que é "Sorrir pra não chorar", eu tinha 16 anos quando compus, minha irmã me ajudou a fazer e tal...

Então sempre compus e não me dediquei tanto a instrumentos de percussão que eu gosto muito, então eu toco um pouquinho de percussão, mas é uma coisa não profissional, uma coisa mais pra "encher" mesmo (risos)...

Pergunta: A composição começou na tua casa? 
Resposta: Na minha casa, sempre, porque meu pai compunha, meu pai tinha músicas dele, sambas dele e tal, então eu segui também nesse vértice. Sempre procurando escrever, e as poesias foram virando músicas, música em escola, muitas vezes às vezes pra teatro, pra brincadeira, ou pra decorar, estudar matéria e aí foi rolando, virou um vício...

Pergunta: Como é a organização do grupo? Como vocês se comunicam? Como vocês se conheceram?

Resposta: A gente se conheceu, porque o Magno e o Maurílio, aqui no Samba da vela, deram a oportunidade, convidaram a gente para fazer um trabalho, uma apresentação de uma roda de samba exclusivamente feminina no mês das mulheres, em março de 2008.

O Chapinha que já conhecia a Zanza e a Elisa que faziam parte do Samba da vela, antigamente, que são da Zona Leste convidou as meninas. A gente montou aquele grupo, montamos o repertório, eu fiz uma música das mulheres da Vela.

A gente já participava do Samba da Vela, como compositoras, cantando e atuando todas as segundas-feiras.

Mas nós fizemos uma roda com mulheres, tocando, mulher no cavaco, na percussão geral, no pandeiro, no tamborim, no surdo, eu arrumei um afoxé, fiz um pouquinho de percussão, tem o shakebalde que eu toco um pouco também.Então, a gente juntou essa galera, umas meninas do feitiço de mulher também.

Fizemos a apresentação, foi muito legal, todo mundo adorou e tal, e a partir daí, o santo bateu... Quando a gente encontra pessoas que bate mesmo... Então a gente olhou uma pra outra e disse: "A gente precisa disso, a gente precisa de mulherada se reunindo", não pra ser uma coisa individualista ou separar dos homens, mas não, uma coisa que agregue mais as mulheres, que às vezes a mulher fica constrangida por chegar a uma roda e ter uma ou duas mulheres e a maioria serem homens.

As mulheres por serem minoria, participando ativamente nas rodas de samba, às vezes parece que a gente está pedindo licença, pedindo um espaço. Então para que isso não fosse apenas no mês de março, ou só pra quem era compositora da Vela, nós resolvemos montar uma comunidade onde a mulher tivesse espaço pra mostra o que faz, se ela faz poesia, se ela também faz samba, se ela toca alguma coisa, se ela toca percussão, se ela toca harmonia, onde ela chega ela se sente a vontade, porque aí elas olham uma pra outra e falam: "Nossa, é só mulherada? Que maravilha!", então ela fica mais solta, mais a vontade. Por isso a gente pensou em fundar essa comunidade. 
A partir daí a gente fez uma apresentação na "Rua do samba" com um monte de gente boa, muita mulherada que está aí atuando...

Pergunta: Ainda era na General Osório?

Resposta: Sim, sim, não tinha mudado para o Anhangabaú ainda. E agente fez essa apresentação lá com Duda Ribeiro, com um monte de gente, muita gente boa, Elizete da Vai-Vai, mais um monte de gente, tanto com quem já estava no samba a "mile ano" que tem muita mulher no samba, trabalhando, cada uma trabalhando no seu cantinho, mas atuando no seu cantinho.

A gente viu então esse espaço e pensou:Vamos pensar grande? Vamos pegar essa mulherada, que cada uma está fazendo um pouquinho em cada região, em cada cantinho e vamos botar numa roda, num lugar, vamos dar uma centralizada, vamos dar uma fechada nisso.

E a partir daí a gente começou com o Samba D’Elas, fez um ano em março, que foi realmente quando a gente começou, porque na semana seguinte da apresentação no Samba da Vela, a gente já se reuniu, já montou o esquema, já arrumamos um local, e começamos. No começo era só para fazer um ensaio, aí o negócio repercutiu legal e a gente foi se influenciando, e a cada quinze dias a gente se apresenta lá na Penha...

Pergunta: Já começou na Penha?

Resposta: Já começou na Penha; Nós começamos itinerantes, firmamos itinerante e começamos a visitar as comunidades, mas o local fixo que a gente faz aniversário agora final de julho, 30 de julho, a gente faz 1 ano de Raízes Bar, que é onde a gente está com nossa comunidade firmada no local, mas essa comunidade já existe desde março, que então de março a julho a gente ficou em uma coisa itinerante, a gente visitava as comunidades, participava das comunidades e a gente fazia encontros na casa do pessoal da Zona Leste, fazia encontros aqui na zona sul, sempre um pouquinho lá , um pouquinho cá, porque metade das meninas são da leste, metade são da sul, então a gente marcava encontros lá e cá periódicos, par estar firmando e agente foi... Pagode da 27, a gente teve apresentações na Via- Vai, Vila Maria Cursi, na Vela mesmo, então a gente foi indo, foi indo, foi indo, até ter um local fixo.

Pergunta: Fora a comunidade do Samba D'Elas, você participa de mais alguma comunidade?

Resposta: É tem a comunidade do Samba D'Elas específica que eu falei que é das mulheres, nós temos os meninos que ajudam: o Marcos Moraes, tem o Ser- 
ginho no violão, tem o Beijoca que toca cuíca com a gente, que dá um apoio, só que eu participo também do Samba da Vela, que é anterior, já tem mais de quatro anos que eu participo como compositora do Samba da Vela, e a gente faz assim, as carreiras solos (risos)...

Quando tem apresentação a gente vai, já me apresentei na Vila do Samba, na Vai-Vai, individualmente falando e com as comunidades, tanto com o Samba D'Elas, como com o Samba da Vela, em Santos, na praia, no Ouro Verde, no Morro de São Bento, tudo quanto é lugar eu já fiz trabalhos individuais e com as comunidades.

Já fiz também trabalhos em Piracicaba, também com o SP em Retalhos, que é um projeto do Junior do Peruche, que ele tenta resgatar os sambas de São Paulo e valorizar o samba e os compositores de São Paulo, sejam eles reconhecidos ou não, antigos ou não, mas é exclusivamente com o pessoal de São Paulo, então a gente também faz esse trabalho onde acontecem apresentações na galeria Olido, no Centro Cultural, no SESC, enfim a gente vai correndo atrás, é a mulherada atuando aí em tudo quanto é lugar.

Pergunta: Pra fechar, me fale mais da sua vida profissional e pessoal.

Resposta: A vida profissional ainda está meio complicada por que hoje eu trabalho como professora, dou aula o dia inteiro em escola Estadual e Municipal, então está fechando o cerco, né?! Tô vendo a hora em que eu vou ter que optar por um lado ou pelo outro. A minha carreira profissional hoje é essa, como professora, dou aula de Português de manhã e a tarde pra molecadinha, pra crianças.

Pessoalmente falando, estou separada há 4 anos, o que me deu mais liberdade também, de estar participando, então todas as comunidades que me chamam eu vou, pra Guarulhos... Seja pra onde for, eu vou, eu participo, eu corro, então, apesar de complicado é muito gostoso, é muito prazeroso, então, role grana ou não é a vida que eu escolhi e não dá pra fugir mais, já era (risos)...

\section{Aparecida dos Santos Camargos (Cida), 43 anos, canta, compõe e toca pandeiro}

Pergunta: Conte um pouco da história do Samba D’Elas

Resposta: O Samba D'Elas foi um encontro não programado, especificamente pra atender uma... O dia internacional da mulher, todo mundo lembra que mulher existe no dia internacional da mulher, né? E aí no circuito cultural em geral 
eventos acontecem, e dentro do samba não é diferente. O Samba da Vela, até por conta de ter o patrocínio da Natura, não sei, mas eu acho que foi até uma existência deles, da própria Natura que é direcionada para o público feminino, de ter essa homenagem acontecendo.

Então, organizaram um encontro de mulheres. Intérpretes, musicistas, percussionistas pra esse evento, às vésperas... Foi no próprio dia internacional da mulher, ou um dia depois, aqui no Samba da Vela mesmo.

Antes desse evento a gente programou e o Chapinha e o Magno, do Samba da Vela organizaram um ensaio para que a gente não fizesse feio na apresentação (risos)...

Então nos encontramos, estávamos eu e minha irmã, Elisa, Zanza (que são irmãs), ainda veio a Thais que era amiga delas e três meninas que eram do Feitiço de Mulher, basicamente era essa a composição da roda. Havia outras mulheres, tinha a Vó Suzana, que era do próprio Samba da Vela, e outros nomes, Soninha, enfim vários outros nomes de mulheres que já tinham sido do Samba da Vela, mas que já não freqüentavam com muita freqüência, mas estavam neste evento.

Aí, agente fez um negócio bonitinho, montou um repertório, pegamos músicas todas das próprias meninas que estavam nessa roda...

Pergunta: Quantas no total?

Resposta: A gente estava ali num grupo de umas 12, de 12 á 15 nomes femininos, entre musicistas, ritmistas, compositoras e intérpretes. Aí foi um encontro que rolou uma super química, a gente se encontrou, se olhou e falou: "Que loucura cara, a gente tem que tá junto!”.

Eu particularmente já vivenciei, eu tinha uma vida já dentro do samba. Eu tinha tido um grupo, e nesse grupo eu fiquei 10 anos.

Pergunta: Esse grupo era formado por homens e mulheres?

Resposta: Só homens, eu era a única mulher. Começou a princípio, eu e mais duas meninas, mas logo no primeiro ano essas duas meninas saíram, por problemas internos, e aí acabei ficando, então eu era percussionista, eu era pandeirista e vocalista do grupo.

Esse grupo durou 10 anos de estrada, de vida noturna mesmo, então Bela Vista, Bexiga são os bairros que na época, há 15 anos eram circuito do samba, então era muito Pinheiros, não Vila madalena. Vila Madalenas ainda não era circuito 
do samba, mais Pinheiros, Bela Vista, Bexiga e alguns bairros afastados, a gente fazia muito evento, muito esse circuito, os barzinhos, feijoada, rolava muito nos bairros, na zona leste, tinha parte dos meninos que era na zona leste.

Eu não tinha espaço enquanto mulher no circuito de samba, eu era uma mulher no meio dos homens, junto com os homens.

\section{Pergunta: E como era?}

Resposta: Era complicado, não com os meninos, porque a partir do momento em que eles me aceitaram no grupo então eu garanti com essa formação, com esse time, eu ganhei respeito, só que em vários lugares que eu chegava junto com os meninos, havia um descrédito, no sentido de olhar e falar assim, bom... Até mulher cantar era uma coisa normal, natural, a mulher cantora, a mulher sambista, tem alguns nomes aí nesse circuito que já são reconhecidos, mas a mulher tocando no meio de homem é uma coisa que você vê mulher tocando junto, homem tocando junto, eventualmente espaço aberto à mulher, mas a mulher tocando sempre com os homens é uma coisa de agora, no Rio de Janeiro, você vê agora, mas é uma coisa muito recente, é uma coisa só para algumas, ainda não é uma coisa que acontece em larga escala, não é uma coisa que fala: "Em toda a roda de samba tem mulher, tocando, cantando compondo, interpretando, mostrando o que é seu".

Você tem algumas precursoras como Ivone Lara, Jovelina, Clementina de Jesus então são alguns nomes que vieram aí na contramão, no sentido de ter o talento mesmo, não ficam naquilo de corpinho bonitinho, gostosinha, carinha bonitinha, corpinho bonitinho, vamos abrir espaço, porque são meninas, no sentido mesmo de garantir aquilo que todos os homens fazem.

O samba tradicional é muito conservador, é muito machista, a sociedade toda é, né? Dentro do samba tradicional, do samba de raiz, como hoje é chamado, porque hoje é moda falar "Samba de raiz", uma coisa que antes todo mundo dizia "Pô, samba de véio", ninguém queria. $\mathrm{Na}$ época do meu grupo quando eu colocava no meu repertório músicas de cantores antigos, menos atuais, se eu colocasse Cartola, Adoniran, se eu colocasse alguns nomes no repertório era "Lá vem a Cida cantar samba de véio", hoje não, a gente tem até nas rádios, em TV a cabo você tem lá o samba de raiz, você chega a qualquer discoteca você tem ali um hall, um acervo direcionado para esse enfoque, o samba de raiz que nada mais é que o samba nos moldes tradicionais, nos moldes convencionais.

Também tem o circuito do pagode que já faz uma linha mais moderna, que vem com metais, que vem com uma banda pop, com os cantores bonitinhos dançando, com jogo de cintura, atraindo as menininhas, então é outro enfoque, que eu acho importante também. Dentro do aspecto, do conceito de samba, amplo do 
samba, eu acho que essa manifestação é importante também.

Pergunta: Por quê?

Resposta: Porque há pessoas que começam ouvindo pagode e a partir do pagode se apaixonam pelo samba de raiz ou outras vertentes do samba, como o samba regional, a escola de samba, a Escola de samba do Rio de janeiro, a Escola de Samba Paulista, então você tem várias vertentes.

Então o pagode, abre portas nesse sentido hoje, principalmente para o público jovem. Antigamente, na minha época de adolescente, pra você ouvir samba, ou você vivia num contexto de escola de samba ou tinha esse conceito de samba tradicional.

Quando vieram, as "modinhas" que a gente fala, os "pagodinhos", essa coisa do "Raça Negra", "Raça Brasileira", o "Só pra Contrariar", vieram numa linha que começou a agradar esse público jovem, e muitos deles começaram a prestar atenção ao samba e a mídia deu espaço pra esse samba.

O samba de raiz só teve espaço, como tem até hoje, na rádio USP, com Moisés da Rocha no "Samba pede passagem". Lá você tem o samba de raiz que acontece, não sei há quanto tempo, mas nas minhas contas acredito que há 20 anos que esse programa existe, é uma hora de programa diário direcionado especificamente para o samba.

A "modinha" hoje toca em qualquer rádio, mas houve uma época, que você podia sintonizar em qualquer rádio $\mathrm{FM}$, em algumas $\mathrm{AM}$ você até achava, mas era isso, você não ouvia samba em rádio, não havia espaço na mídia par o samba, eu vivi isso!

Pergunta: Televisão então?

Resposta: Televisão (risos)... Não. Começou a abrir mais espaço para o samba, um pouco Fundo de Quintal, Zeca, Jorge Aragão... Você tem nomes pontuais.

Pergunta: Beth?

Resposta: Sim, Beth Carvalho, mas ela não era do samba, como Maria Rita, ela era da MPB. Ela veio no mesmo perfil, começou com MPB, não era do samba depois ela virou, mas inicialmente os primeiros trabalhos dela não...

Pergunta: Clara Nunes também? 
Resposta: Clara Nunes já foi focada do samba, inclusive essa coisa de samba de terreiro, da umbanda, o estilo visual dela também já veio direcionado pra isso, mas a Beth Carvalho não... E aí vou falar uma coisa que as pessoas chocam quando a gente fala, mas é inevitável. Antigamente o samba era mais negro do que hoje, antes em um grupo de samba você tinha 9 negros e 1 branco, ou um mesticinho mais clarinho. Hoje em dia num grupo desses de mídia, você tem 9 brancos ou de pele clara, vamos colocar assim, porque a gente vive em uma país miscigenado, pluricultural, então a cor da pele ela engana, ela induz, né!? Mas se você olhar na mídia hoje, vária grupos vários cantores tem esse aspecto físico da pele clara e não se denominam afro-descentes, e são os que estão macicamente na mídia.

Vamos até abrir um parêntese, por exemplo, contraditoriamente na Bahia, um grande pólo de concentração de negros ou afro-descentes, quantos negros você vê na mídia? Você encontra Margareth Menezes, O Olodum, O Ilê Aiê, mas quem está na linha de frente dos trios elétricos? Margareth Menezes...

$\mathrm{Na}$ Bahia $70 \%$ da população é negra de pele. Aí você me pergunta: "Ah mais você está querendo segregar?”. Não, tô dizendo que a mídia é contraditória à manifestação que você vê nas suas raízes.

E para a mulher então, no sentido de ser musicista, você vê muito no exterior, bandas importantes. Beyoncé, por exemplo, ela tem a banda dela, com coral feminino, baterista, guitarrista, contrabaixo, é só mulher tocando muito! Não acho que deva haver a segregação, mas as mulheres aparecem de fato, numa proporção bastante intensa. E aqui no Brasil ainda é uma coisa meio brigada. É dessa maneira que eu enxergo, por conta da idade que eu tenho e da bagagem, de histórico, da vivência, e dentro desse samba tradicional não é diferente.

Não fosse assim, não haveria surgido o Samba D'Elas - Herança de Ciata, que é justamente uma possibilidade da gente estar em um espaço, em um contexto da gente, numa roda, não par segregar, porque em um primeiro momento a gente até pensou: "Ah! Agente vai fazer o "Clube da Luluzinha e acabou"! "Não, a gente manda, mas a gente permite que os homens sentem conosco e façam parte da roda de samba.

Diferentemente de outros lugares, por exemplo, no Samba da Vela, você não vê as mulheres tocando junto com os homens. Você vê, por exemplo, como esse ano também aconteceu, as mulheres num momento a parte dos homens, ou até cantando...

Pergunta: Ou como convidadas...

Resposta: Sim, como convidadas, mas tocando na roda, tocando instrumentos 
não! Na retaguarda sim, mas naquela retaguarda, até porque os diretores são 4 homens, então até é natural esse posicionamento. Mas se fosse um espaço, de fato, $100 \%$, eu não precisaria nem estar falando, isso seria natural, não precisaria estar pedindo nem falando. Isso não é uma crítica para depreciar o Samba da Vela, é uma observação pontual do que eu vivo, porque eu sou do Samba da Vela.

Pergunta: Há quanto tempo você está no Samba da Vela?

Resposta: A gente está aqui, no Samba da Vela, há 5 anos.

Pergunta: Você e a Ana?

Resposta: Sim, eu e a Ana, 5 anos de participação, então a gente vivenciou e tem vivenciado. A gente é assídua, a gente participa freqüenta de fato nesse contexto, porque a gente conheceu amigos, a gente descobriu outra frente, devido a essa linha do samba tradicional, que é focado nessa coisa de produção musical. Essa coisa de você ter oportunidade de mostrar o seu trabalho fora do circuito da mídia.

O que se faz aqui (Samba da Vela), o que se faz lá no Samba D'Elas mídia nenhuma mostra. O Samba D'Elas vem com esse mesmo formato.

Pergunta: É intenção do Samba D'Elas, de uma maneira ou de outra, chegar à mídia?

Resposta: Se a mídia nos der espaço, por que não?

A gente não tem a intenção de descaracterizar o trabalho que a gente faz. Lógico que parte do que a gente faz, é apresentar o que a gente compõe, o que a gente cria, mas é também valorizar, reproduzir, mostras coisas boas e importantes que já aconteceram que foram gravadas, porque é uma coisa assim, você tem que atingir um aspecto comercial da coisa e o samba, a música, ela tem esse cunho. Senão, fica aquela coisa assim: Ah eu faço música só pra mim, pra ficar na gaveta, pra debaixo do colchão? Não é?

Acho que todo mundo gostaria de ver aquilo que produz aquilo que cria aparecendo de alguma forma, em algum lugar. E o acesso à mídia, se for no sentido de reconhecimento, de valorização do que a gente faz, reconhecendo esse formato do nosso trabalho, é uma intencionalidade sim, acho que até natural.

Por exemplo, a gente viu o que acontece com o Samba da Vela. Tem um espaço, tem um reconhecimento, um respaldo. Ah mas se você me perguntar: Vocês 
tem a pretensão de ser tornar o Samba da vela? Não, a gente tem a pretensão de fazer o que a gente faz ser conhecido. Então se a mídia é uma forma, uma ferramenta dessa percepção, eu acho natural que a gente vise sim, determinados espaços e espaços culturais. Agente quer estar sim nesse circuito de SESCs, nesses circuitos de Casas de Cultura, nesses trabalhos assistenciais, perto da comunidade. Para que quem tá chegando, quem é mais novo, não demore 20 anos de estrada pra ver o que eu estou vendo hoje. Para que possa já novo, já tenro, como a gente tem, por exemplo, a Bia, que é do surdo. Ela tem 18 anos e já vem no samba tradicional, no samba de raiz, e tem a possibilidade de estar conosco, num contexto, junto com outras mulheres, que estando junto fortalece. O objetivo não é a segregação, mas é a ampliação de espaço e manutenção dessas coisas que são positivas, acho que fica dentro do contexto do samba. Basicamente é isso.

Pergunta: Me conte mais da história do Samba D'Elas

Resposta: Então, o Samba D’Elas foi uma química. Depois da apresentação no Samba da Vela, a gente foi numa apresentação do Samba da Tenda. A gente programou de ir no Samba da tenda, porque parte das meninas daqui, a Zanza, a Elisa e a Thaís, que cantavam no Samba da Tenda, não era a Cida, mas a Cida freqüentava também o Samba da Tenda. $O$ pessoal de lá então nos convidou para fazer uma roda similar ao que a gente tinha feito no Samba da Vela, lá no Samba da Tenda. Aí fizemos a apresentação lá. Aí já estava nítido, nas entrelinhas, que a gente ia continuar, que não tinha como retroceder, que era uma liga que tinha rolado tão natural.

Depois disso, nós fizemos mais uma apresentação na Rua do Samba Paulista, que era na General Osório e agora está no Anhangabaú, por causa da reforma.

\section{Pergunta: Vai voltar pra lá?}

Resposta: Não sei, acredito que depende do que vão fazer ali no sentido cultural. Talvez seja mais interessante manter o samba pra cá. Depois de certo tempo, a gente cria a identidade com o espaço. Acho que para o pessoal do projeto, Samba Autêntico que chama, acho que eles têm a intenção de voltar, mas pode ser que daqui a algum tempo essa intenção mude, de acordo com o formato, $o$ desenrolar, a aceitação das pessoas com relação a esse novo espaço.

Então, quando a gente fez a roda de samba lá, era uma outra coisa, pois não era uma coisa restrita ao Samba da Vela, ou ao Samba da Tenda. Lá você tinha mulheres, muitas mulheres que atuam em diversas vertentes do samba numa 
maneira geral. Muitas interpretes, muitas percursionistas, aí você tinha as meninas do Feitiço de Mulher, do Pura Raça, basicamente a roda foi essa. Isso rolou naturalmente.

Pergunta: Quem tocou na Vela da primeira vez?

Resposta: Eu e minha irmã da Vela, as meninas da Tenda e as do Feitiço de Mulher.

Pergunta: Quem eram as meninas do Feitiço de Mulher?

Resposta: Na época estava a Digena, Camia e Gilda, se não me falhe a memória, mas a Tati, não lembro se veio. Na Rua do Samba, elas foram, formas as outras meninas do grupo. O Feitiço de Mulher é um grupo feminino, mas não é focado no samba tradicional, o samba de raiz, é um samba que está no circuito comercial, na linha das modas, dos pagodinhos, a veia não é a do samba tradicional, do samba de raiz. Elas até cantam, mas não é a veia do trabalho delas. Elas estão num circuito comercial de trabalho, convencional vamos dizer assim.

Que é aquela história, que eu acho de grande importância, apesar de ter gente que diz: Ah isso não tem validade. Pra mim tem validade, pois atinge outros públicos que começam a se afeiçoar ao samba e de repente descobrir outras possibilidades até chegar no samba de raiz, ai abre uma portinha, um canal.

E aí depois desses três encontros a gente marcou uma reunião. "Não nós precisamos começar pra fechar, porque a gente já está fazendo! Então vamos por no papel o que a gente está fazendo, porque é! É isso que nós vamos fazer".

Nesta reunião nós começamos a estabelecer o perfil do que seria nosso trabalho. "A mais vai ser um projeto? Vai ser uma comunidade"?

Pergunta: Quem teve esse estalo de falar "vamos fazer"?

Resposta: Eu, a Ana, a Elisa e a Zana, a gente estava nessa linha de frente. Foi uma coisa se empatia mesmo, muito grande, porque eram duas, e mais duas e todas de personalidade muito forte. Em linhas gerais, todas as mulheres que estão no Samba D'Elas, a genialidade, a personalidade, se não fosse assim a gente não ia ter chegado onde a gente está. Dá muito confronto também, mas acho que essa coisa de falar "vamos fazer" foi uma predisposição coletiva.

Eu forcei muito, porque é uma coisa, pelo meu histórico de samba, pelo fato de ser mais velha e de tido essa vivência no contexto masculino do samba, meus 
olhinhos brilhavam, pulavam com essa idéia de ver isso acontecer. Quando eu percebi que as meninas tinham essa vontade, então vamos otimizar isso, vamos colocar isso em prática. Aí, veio a questão do nome, que na verdade a gente tinha 3 possibilidades de nome: seria Samba D'Elas ou Herança de Ciata. De várias possibilidades de nome, ficaram essas duas. Como uma metade queria Samba D'Elas e a outra Herança de Ciata.

Por que Ciata? A tia Ciata era uma tia baiana, tinha uma casa, um terreiro, e abria as portas para o samba lá no Rio de janeiro. Há quem questione aqui em São Paulo o porquê a gente pegou o nome de uma mulher do Rio e não de São Paulo e na verdade, a gente entrou nesse foco de discussão.

A gente tem que tomar certos cuidados e carregar nomes, você carrega junto a responsabilidade em contrapartida, a gente queria, as meninas né, que queriam muito Herança de Ciata, acharam que era uma homenagem importante de um nome importante dentro do samba.

E o "Samba D'Elas" seria mesmo pra mostrar que é o lugar onde as meninas estão. Pra deixar claro que é mulher no samba, ponto. Então com o "Samba D’Elas" ficou muito nítido.

A gente não sabe se vai ter problema para registrar, porque a gente ainda está nesse processo de registro e formalização, mas acredito que a gente vai manter parte desse nome. A gente não sabe se vai haver alguma objeção dos parentes da Tia Ciata, com relação à citação do nome dela. Que na verdade, é uma homenagem a ela e ao trabalho dela.

Então a gente entrou nessa discussão do que a gente ia fzaer com o nome. De repente eu virei e falei: “E se a gente juntasse os nomes? Samba D'Elas - Herança de Ciata?" Aí passei a idéia para minha irmã e ela gostou.

Ela com as meninas: "Meu, vai ficar grande! É... vai ficar grande, mas a gente mata as duas coisas! A gente deixa clara a intencionalidade do trabalho e faz uma referência, e faz uma homenagem à Tia Ciata", que na verdade é para homenagear as mulheres do samba.

Ah! Mas aqui não tinha mulher de São Paulo? Tinha, mas enquanto nome reconhecido, de registro, a tia Ciata não foi a única, mas foi uma das precursoras, $\mathrm{e}$ que teve a casa mais reconhecida e freqüentada por vários nomes importantes. Dentro dessa ótica agente quis arriscar e manter esse nome por conta desse perfil. A gente quer não restringir.

Quando eu cito: Leci Brandão, Ivone Lara, Beth Carvalho, Clara Nunes, são nomes que não estão dentro do samba paulista. Por quê? Por que o reconhecimento do samba Paulista é posterior.

No samba paulista você tem a questão do samba regional, que é diferenciado, e 
você tem historicamente falando registros posteriores. O samba do Rio ganhou frente e reconhecimento muito antes do samba de São Paulo ter sido reconhecido. Tem gente que mistura as duas coisas, que coloca no mesmo baú, na verdade não. Aí você tem toda uma questão de estrutura, a estrutura da cidade...

Enquanto você tem lá no Rio de Janeiro o samba saindo da margem e subindo o morro, aqui em São Paulo, o samba acontece no circuito interiorano, juntamente com os negros africanos, os afrodescendentes, os recém-libertos e a mistura dos imigrantes que começavam a chegar as grandes fazendas, trabalhando nas grandes fazendas. Então você vê culturas se misturando e ai você tem frentes importantes, então há divergências, no sentido de que samba surgiu nesse interior de São Paulo, e hoje é chamado de samba regional, que são os jongos, os batuques. Hoje você tem o Osvaldinho da Cuíca, o Júnior do Peruche que traz essa defesa do samba do interior de Piracicaba, enfim esse samba dito regional.

Aí você tem uma discussão histórica e você vai perceber que em alguns momentos cruzam-se algumas informações. E que informações são essas? No samba regional existem instrumentos que não existem no samba convencional. A zabumba, por exemplo, que é o samba do bumbo, que começou a ser usado aqui em São Paulo. E tem o samba do Rio de Janeiro, que é um outro perfil de samba, então você tem raízes que se misturam. Aqui em São Paulo hoje se tenta fazer um samba igual ao do Rio, porque eu digo tenta? É complicado porque cada um tem a sua especificidade. A gente tem realidades diferentes. A gente teve aqui em São Paulo, pólo de trabalho, de industrialização, e nisso nós somos precursores, o foco de trabalho, de demanda das indústrias ficou aqui em São Paulo, não era no Rio de Janeiro.

O Rio de Janeiro era uma cidade de chegada, e o samba, eu não sei ainda te dizer, é uma coisa que eu estou estudando, tentando me aprofundar até para argumentar melhor, mas lá o samba ficou e o foco de trabalho aqui em São Paulo.

Aqui em São Paulo não tinha preferiria. Tinha a cidade de São Paulo e as cidades no interior, as fazendas que viraram cidades, como Tietê, Piracicaba, onde tinham grandes circuitos de plantação, de campos de trabalho e depois sim que as periferias começaram a surgir.

Santo Amaro mesmo, não pertencia a São Paulo, não era capital. Você tinha Centro, Avenida Paulista, que os grandes barões do café compravam suas grandes casas, no centro, nos bairros próximos, e o que era periferia, na época era Barra Funda, Bexiga, Bela Vista, então as periferias eram bem próximas do centro. Num raio de $10 \mathrm{~km}$ você tinha as periferias ali. 
Hoje se você puxar do marco central ali na Praça da sé, num raio de $30 \mathrm{~km}$, você vê que as periferias estão a partir daí, hoje. Se você pegar santo Amaro, nós estamos há $15 \mathrm{~km}, 18 \mathrm{~km}$ do centro. $\mathrm{O}$ bairro onde eu moro, por exemplo, dá uns $25 \mathrm{~km}$ até o centro.

O formato da cidade é o outro, o perfil é outro. Muitos imigrantes, muitos migrantes, gente me busca de trabalho, de promessa de futuro, então são Paulo passou a ser uma cidade focada para o trabalho. Essa coisa do samba se perdeu um pouco por conta disso, por causa deste direcionamento, desse enfoque comercial, industrial, de plantação e tudo mais. É uma coisa mais pra aprofundar em pesquisa. Posso estar falando besteira em algumas coisas, mas estou procurando buscar embasamento pra sustentar essas coisas que a gente faz.

E o Samba D'Elas quer manter um pouco, disso aí, dessa raiz, desse trabalho que os homens fazem e que de uma certa forma nos deixa meio fora. Ah agente é muito assim: a cabrochinha ou a retaguarda. Todo mundo fala da cabrocha.

No samba tradicional você vai ter ou a mulher "zuada", demais! "Zuada" no sentido atual ou depreciada. Porque ou ela é a coitada, tipo Amélia, ou ela é aquela a perdida, a bandida, a safada, entendeu? Ela vem nesse sentido pejorativo, no samba tradicional.

É engraçado que nas modinhas a mulher vem como a amada, a paparicada, a "cocotinha", a "tchutchuquinha", eu te levo pro samba meu amor, "vem cá meu bem", meu benzinho, meu docinho, e no samba de raiz não, até tem, mas via de regar, quando vem o samba de raiz falar da mulher, vem pra falar mal da mulher, ou vem pra falar: "poxa eu sofri muito por você!" Poxa, mas não é aquela coisa, as composições que tentam manter essa linha, no o samba de raiz, ainda vêem a mulher como peça decorativa. Ou é muito bonitinha e tá na moda, decorou legal, ou então já saiu da moda.

O Samba D'Elas vem com esse propósito de revelar. Contraditoriamente a nossa proposta, quem tem prestigiado mais o nosso trabalho são homens. $70 \%$ do público freqüentador das nossas rodas de samba é um público masculino, uma estimativa.

Nessa semana até comentei com umas meninas: "Vai lá...”. E elas: "Ah porque você não falou que tinha bastante homem, se tem bastante homem a gente vai" (risos). Te juro!

A gente chama as mulheres e elas dizem: "Ah, mas não convidou! Mas a gente não sabe direito onde é. Mas como é que é"?

Aí eu digo: "Ah! Roda de Samba de homem, ninguém precisa mandar convite que você vai né? Descobre, chega de olherada". 
Pergunta: E as mulheres da própria Penha?

Resposta: Mesmo mulheres ativas, agora que começou. Antes você tinha lá, a Vó Suzana, Tia Dita, as meninas da Vela, que já estão acostumadas a ver a gente na Vela...

Pergunta: Mas esse pessoal não é de lá, certo?

Resposta: Quem freqüenta a Penha, a Gê que já era de lá, a Soraya, desse circuito do samba, mas quem diz: "Ah agente tá indo lá pra ver vocês", são poucos nomes. E tem muita mulher, a gente tromba as meninas nas comunidades.

Pergunta: E por que você acha que acontece dessa maneira?

Resposta: Porque ainda tem resistência, mulher infelizmente rejeita o trabalho de mulher, no samba. Não to dizendo inclusive que seja uma coisa intencional.

Pergunta: Sabe o que eu acho interessante, essas mulheres de fora que poderiam participar até como convidadas e tal...

Resposta: Não aparecem! Assim, estão pagando pra ver. Mulher duvida do trabalho de mulher, eu acho! Inconscientemente às vezes, não é por maldade. Às vezes eu penso que tem uma coisa de: "Poxa eu chego na roda de samba e quero ver mulher tocando? Eu chego na roda e quero ver os caras tocando!". É um pouco dessa cultura, não é habitual, não estão acostumadas com esse tipo de coisa, então você vai ter que convencer as pessoas de que é um projeto legal.

Mas você tem muita mulher, porque tai um negócio que é meio contraditório, porque como eu te disse, uma coisa que a gente se assustou na "Rua do Samba Paulista". Teve mulher que não conseguiu cantar, tem menina que não conseguiu tocar, tamanho o volume de pessoas para se apresentar.

Esse ano houve a Rua do Samba, e a gente deu uma delimitada no sentido de "Olha, vai entrar e cantar uma música, no máximo duas. Vai tocar, vai ter uma roda básica, para não diferenciar muito o estilo de apresentação, de ritmos, de percussão". A gente manteve ali na roda um básico da percussão, pra não quebrar muito o andamento, os ritmos da percussão e pra não ficar esse negócio de troca um, troca outro... Que é um negócio até natural de acontecer em roda masculina. Até por conta do hábito desse tipo de rodas femininas acontecerem,hoje, a gente tem muito mais flexibilidade, jogo de cintura, do que a gente tinha a um ano atrás, quando nós começamos. 
Pergunta: Por causa de...

Resposta: Dessa intimidade, de sentar ali, de uma já olhar pra outra, da intimidade do repertório, do que você vai cantar, de dar encaminhamento para a seqüência da roda de samba, sejam músicas inéditas ou não.

A gente fica chateada por um lado, mas agente sabe que é uma coisa que também se você pensar, por exemplo, de 50 comunidades, você pega a revistinha da periferia, não sei contabilizar quantas, mas vamos jogar, entre trinta e quarenta comunidades, você ter uma única feminina, que é a nossa, com um ano, poxa! Eu não estou dizendo que este tipo de trabalho não aconteça, mas oficialmente é a nossa.

Pergunta: Você conhece alguma outra?

Resposta: Olha, comunidade com continuidade... A gente sabe assim, existe um espaço, uma vez por mês, ou uma vez por ano lembra e faz-se um trabalho, ou a abre se um espaço para a mulher, sim, por exemplo, na Rua do Samba, a gente abre um espaço para a mulher, mas é naquele momento, que se abre um espaço para a mulher, depois acabou. Inclusive tem as meninas que estão lá a Nei e a Fernanda, que são do Projeto "Samba Autêntico", da Rua de Samba Paulista, mas eu particularmente vejo que é uma participação muito modesta. Quem manda mesmo são os homens e o espaço é assim, um tamborinzinho, um coro, até abrem um espaço, mas parece que as mulheres se intimidam ainda, porque a grande maioria são homens ainda.

Se dá, também, muito espaço muito de boca (vocal)! Porque eu não tenho vergonha nenhuma de sentar aqui e tocar um pandeiro. Pergunta pra mim quantas vezes eu toquei sem ser na roda das meninas?

\section{Pergunta: Aqui? (Samba da Vela)}

Resposta: Uma vez! Um dia, faltou um monte de gente aí, o Paquera virou pra mim e falou: Nossa não tem ninguém pra fazer. Vou chamar fulano... Vai ficar complicado! Aí ele falou assim, Cida você segura o pandeiro um pouquinho pra mim? E ele veio falar isso pra mim. E eu falei: é tá complicado hoje, vê o que você consegue! E ele: Ah acho que o Paulão, talvez o fulano de repente segura.

Pergunta: É um costume né?

Resposta: É um costume, e não é só aqui. Isso também acontecia quando eu era panderista do meu grupo, tocando com o meu grupo, e vinha homem me 
tirar do pandeiro, ele achava que tinha que me tirar dali porque eu estava fora do contexto, dentro desse circuito do samba tradicional.

É importante reiterar sempre a importância do Samba da Vela para nós, o espaço aberto para nós como compositoras e cantoras. A gente se conheceu no Samba da Vela, isso é irrefutável e irreversível, é um mérito que a gente não pode delegar para ninguém. A gente não se conheceu na Tenda, a gente não se conheceu na Rua do Samba, a gente se conheceu na roda de samba no Samba da Vela. Isso a gente tem que deixar bastante claro, porque a gente está fazendo um trabalho paralelo.

Quando a gente começou com o Samba D'Elas. Algumas pessoas pensaram que a gente ia abrir mão do Samba da Vela, que a gente ia deixar de freqüentar para estar no Samba D'Elas, mas não, porque são coisas distintas: aqui a gente tem uma vivência! Lá onde a gente tá, a gente direciona, a gente atua de uma forma diferente. Pior? Melhor daqui a uns dez anos? Quem sabe? Quando a gente estiver no nosso nono aniversário, pode ser... (risos). A gente tem personalidades diferentes, outras características. Diferente já é.

Pergunta: Outras características?

Ana Elisa: Sim, é outra situação. Tanto que a Cida colocou a situação das mulheres, quem chega e quem não chega.

A maioria das pessoas que chegam e apresentam sambas novos, porque o nosso intuito lá é realmente trazer compositores, são músicas inéditas, a maioria das pessoas que apresentam samba lá, são homens.

A gente pode ver pelo Jessé, que freqüenta a Vai-Vai, que eu encontro na praia, ele não perde praticamente nenhum Samba D'Elas.

Cida: Aliás, mulher que apresenta samba ali, acho que é só a Sandrinha. Inclusive agora ela é membro.

Ana Elisa: Ela chegou pra ficar! Agente conseguiu ali, pelo menos uma mulher.

Cida: É agora ela foi "eleita" membro (risos). Ela vem com esse propósito de agregar, se acrescentar conhecimento, valor, disposição, luta, espaço, de tentar frentes aí, mostrar a cara mesmo. Essa coisa de mídia é mostrar a cara mesmo.

Pergunta: Você me falou de uma mídia que é a Revista da Periferia... 
Cida: Isso, a gente está na Revista da Periferia, sabe por quê? Porque a Sandrinha Lima, essa moça que a gente está falando, ela conhece pessoas lá dentro, e quando a gente começou a fazer o trabalho, ela falou: "O que vocês acham? Eu conheço o pessoal, eles colocam todo mundo, vou ver se colocam a gente".

Então, antes de qualquer coisa ela fez contato e no nosso segundo mês, a gente já estava na "revistinha".

Ana Elisa: Aí eles conheceram o trabalho e viram que era um trabalho pertinente, que valia a pena. Não podemos tirar nosso mérito. A Sandrinha conseguiu abrir a porta pra gente, mas a gente conseguiu manter.

Cida: Só se estabelece quem tem competência, e não é enchendo a nossa bola, mas se a gente fosse tão ruim, a gente não teria a possibilidade que a gente tem mesmo a contragosto de alguns. Sempre há, né?

Às vezes falam: "Ah, onde essas meninas pensam que vão, invadindo uma praia de homem"?

Ana Elisa: Também tem aqueles "lances", tem marido que vai ver, tem namorado que vai ver. Você compõe e tem cara que quer que você cante junto com ele. Aí tem menina que não gosta e fala: "Poxa, você está indo em outra comunidade pra tocar, são só mulheres”, ciúmes.

Cida: Porque o homem diz: "Vou chamar meu camarada pra tocar comigo, pra cantar e ta tudo certo! Amanhã ele diz: "Vou chamar minha camarada pra tocar..." E a esposa: "Camarada?! Tô sabendo..."

Ana Elisa: Uma situação que aconteceu aqui no Samba da Vela, como o intuito de apresentar sambas novos, e cantar o samba dos compositores, e nessa de fazer coro, a gente acaba encontrando homens também que as vozes se casam. Com isso, a gente acaba fazendo trabalhos de coro, estúdio etc.

Teve então um rapaz que veio falar comigo que estava fazendo um trabalho em estúdio e perguntou se eu queria fazer e então ele me ligou e pediu que eu retornasse. Quando eu retornei, não era mais o rapaz que estava em casa era a mulher e ela disse meio brava, que daria o recado. Tô até hoje esperando. Quer dizer, a mulher "tesourou" o cara, porque eram mulheres que iam.

Cida: Esse é o problema, tem algumas pessoas que pensam em usar o espaço para "pegadinhas", e na verdade não é isso. Trabalho é trabalho! "Pegadinha" é "pegadinha"! É uma outra história. 
Pergunta: Cida, me fale um pouco a respeito do Samba D'Elas e os homens.

Cida: O Samba D’Elas, apesar de ter uma diretoria feminina, tem a presença de alguns homens. Um menino que está conosco desde quando começamos a fazer o bar é o Marcos Morais, que é do Samba da Vela também. Ele teve a coragem de assumir, pois é um trabalho que a gente faz sem fins lucrativos.

Alguns trabalhos que a gente faz, rola uma grana, mas no momento a idéia não é “A gente vai enriquecer com o Samba D'Elas". Pode ser que um dia isso aconteça, por que não?

Como eu disse, temos o Marcos Morais que está com a gente no banjo. Temos também o Serginho, que veio um pouco depois no violão de sete, que tá com a gente na roda de formação.

Aí temos Batata e Beijoca que fazem percussão geral, cuíca. O Batata também tá junto na parte da percussão, reco-reco, essas coisas.

A gente permite essa participação dos homens, isso já é real. A gente gostaria que tivessem mais mulheres? Até gostaríamos, mas eu particularmente defendo muito que a gente tem que fazer um pouco diferente do que os homens fazem, então a gente ta tentando segregar menos, fazer um trabalho mais em conjunto do que de segregação, do que continuar mantendo as mulheres de um lado e os homens de outro. A gente quer fazer uma coisa que seja mais uniforme. Lógico que isso é um processo, é processual! É um trabalho de formiguinha, até por conta dessa visibilidade, desse respeito.

Tem uma moça do Rio de Janeiro que nós conhecemos há pouco tempo. Ela esteve com o namorado lá no Samba D'Elas e gostou muito do trabalho, mas falou: "Gente, lá no Rio a gente nas rodas, as mulheres estão juntas sentadas".

Quem toca? Quem é conhecida e os caras sabem que tocam e cantam, ficam junto nas rodas com os caras e aqui em São Paulo, as mulheres estão sempre naquela posição das pastoras, das carochinhas, dos bastidores.

Pergunta: Mas ela disse junto...

Cida: Junto, sentadas, atuando. Eu nunca vi, então não posso dizer, mas ela afirmou.

O que ela disse foi que o que cauda mais estranheza para ela nos circuitos de samba de São Paulo, nas comunidades, nas rodas de samba tradicional, samba de raiz que é o que ela curte o que ela vivencia. Ela citou um exemplo, que quando eu vou a rodas de samba, eu tô lá batendo palmas, acompanhando e todo mundo sabe que eu toco, ninguém diz: Cida, vem cá, toca aqui. A gente estava na "Rua do Samba". 
Com isso, eu acredito que eles (Rio), já estejam à frente nesse processo. Aí você tem, por exemplo, o Jorge Aragão tem mulheres que fazem o tantã, fazem percussão pra ele, na banda, nos palcos, nos shows dele, porque ele foi um dos primeiros a colocar mulher percussionista, em um instrumento restrito, geralmente é um instrumento de batuqueiro como a gente costuma dizer.

Tirando essa coisa dos desabafos, das angústias, que é uma coisa natural no Samba D'Elas, a nossa proposta mesmo é isso, de valorização do samba.

A gente obviamente por ser de São Paulo, por cantar coisas nossas, a gente acaba direcionando para o samba paulista, naturalmente.

A gente não quer restringir, porque é a aquilo que eu falei os nomes de mídia que a gente conhece das mulheres sambistas, são nomes conhecidos cariocas.

Mas aqui em São Paulo não tem nomes de mulheres? Até tem, mas são nomes anônimos, como a gente tem no circuito do samba de São Paulo nomes anônimos. A gente ouve falar muito de Geraldo Filme, um pouco de Osvaldinho da Cuíca, Adoniran Barbosa, aí fica uma mão de dez nomes e aí morre? Não, não morre, então são esses anônimos.

Pergunta: E como nome feminino, por exemplo, a Dona Inah?

Cida: Sim, a Dona Inah, ela está viva, atuando e só agora está tendo um certo espaço, mas quantos anos a Dona Inah tem de estrada pra ter esse reconhecimento? Mesmo a mídia dela não é uma mídia na contrapartida dos outros nomes cariocas que a gente vê, como a Ivone, a Jovelina, Clara, Beth.

E por que eu falo? Porque de fato são professoras, isso a gente tem que falar, e olha não é Rio ou São Paulo, é o samba e ponto! Acho que a gente tem que focar para isso.

É legal, é bom, a gente tá fazendo com as nossas características, porque tem vivências que são diferentes de quem está lá no Rio.

Eu não estou no Rio, então a minha estrada, a minha história, influencia aquilo que eu produzo, o que eu escrevo, quem eu sou. Tem lógica essa abertura, mas a minha estrada, minha verdade é diferente.

Pergunta: Conte um pouco da sua história, sua família, de sua vida pessoal.

Cida: Meu pai tinha essa veia autodidata, com violão, pandeiro, flautas que ele mesmo fazia, flauta de bambu, flauta transversal, tirava um som maravilhoso. Ele era autodidata, nunca estudou música, veio de família pobre, foi criado em abrigo de menores. Conheceu minha mãe em Piracicaba, na época ele traba- 
lhava de motorista de caminhão e de trator, ela era professora recém-formada, e em 3, 4 meses se casaram e vieram pra São Paulo.

Meu pai também trabalhou em rádio, foi radialista em 1959, 60, 61 e 62. Isso, antes do namoro, noivado e casamento deles.

Então, essa coisa da musicalidade, era uma coisa que meu pai incentivava muito.

Minha mãe também, mas minha mãe tinha outra forma, porque ela foi criada na roça, perdeu a mãe muito cedo e logo ingressou para o magistério, ela teve pouco contato com a família materna.

Ela foi criada por um irmão mais velho e uma tia. Era uma família que tinha um certo nome em Piracicaba, então ela conseguiu acesso a formação, o que não era comum, por conta de ser de origem pobre. Só por ela ter conseguido entrar no magistério, porque a negritude, na época, em Piracicaba era uma coisa gritante, essa coisa dessa... e ela conseguiu se formar, ser normalista, como se falava na época e se efetivar como professora.

Então quando ela veio pra São Paulo, ela já era professora e meu pai autônomo, enquanto atuação de trabalho.

Tinha as serestas, onde a gente escutava as modas de viola, eles escutavam muito Jamelão, Nelson Gonçalves, Altamiro Carrilho, Vicente Celestino, Maysa, ele era apaixonado por Maysa, Noel Rosa entre outros. Ele tinha uma linha mesclada, então a gente teve um crescimento dentro dessa coisa de musicalidade, mas sem ser focado exclusivamente no samba, então não era uma coisa restrita ao universo do samba.

Depois sim, um pouco mais velha, aí sim por conta de conhecer amigos, fazer uma roda de pagode, de samba. Os amigos se reuniram, juntavam os instrumentos nos fundos de quintais, nas, nas rodas de churrasco, nos bares, nos bairros. Muitas vezes nem tinha instrumento de harmonia, por conta da questão financeira.

Enfim, a maioria dos músicos batuqueiros mais antigos são mais autodidatas do que estudados. Hoje você tem uma legião de meninos novos que estudam o samba e tal, mas antigamente não era o perfil.

Antigamente se fazia o batuque, o samba era muita coisa de ouvido e reprodução de som e muitos se destacavam.

Há ainda alguns antigos estabelecidos que estudaram, mas é uma coisa posterior, primeiro foram aprender a tocar e depois foram aperfeiçoar um pouco de conhecimento técnico para sobreviver nesse universo. Mesmo assim, têm muitos que nem partitura lêem, que é uma coisa exigida tecnicamente falando, em um estudo e tal. 
Eu mesma, ainda não tenho formação técnica. Já fiz um pouco de aula de canto, mas essa coisa de ler partitura eu sei bem pouco. Sei alguns conceitos como solfejo, um pouco das notas mínimas, semínimas, colcheia, mas esses conceitos são superficiais, ainda não é suficiente pra me dar uma sustentação, pra dizer "pega isso e lê".

Ainda nesse contexto musical, eu convivi muito com MPB, black music. Na black music, Michael Jackson, essa coisa de rua mesmo, Lionel Richie, The Commodores, Anita Baker, Diana Ross, Dionne Warwick.

Também tinha MPB, nomes comerciais da MPB. Eu curti muito Djavan, Benito de Paula, Luís Airão, nomes que vem de lá de trás.

Aí, entrei no grupo, que começou como brincadeira, então eu ia mesmo pra ser pastora, pra acompanhar os meninos, pra fazer corpo, porque a voz era uma voz potente e afinada, por conta dessa vivência do meu pai sentar com a gente depois das refeições, e agente ficava cantando diversos estilos musicais. Ele punha os discos de vinil, 78 rotações, a gente ouvia muito. A gente curtia muito, meu pai curtia cantar com a gente, fazíamos tipo de um sarau em família.

Quando eu caí no grupo, o grupo me deu outra vivência, comecei a conviver num contexto de quadra de escola de samba. Já freqüentei muito Vai-Vai, Peruche, muito a Camisa Verde, basicamente essas escolas. Eu fui da ala de compositores da Vai-Vai, as pessoas nem lembram, mas eu fui.

Por conta de estar no grupo eu acabei abrindo mão de continuar com esses trabalhos paralelos.

Pergunta: Como era o nome do grupo?

Cida: Olha que nome modesto, o nome era "Totalmente Demais", por causa de uma música que tinha na época. Porque como a gente fazia um catado e ia tocar a gente não tinha nome e uma vez quando a gente foi tocar em uma pizzaria foram anunciar, precisava de um nome e um dos meninos mandou esse nome e depois pra simplificar ficou TD... O nosso repertório era mais para o samba tradicional, além do samba-rock, tinha muito isso também.

Eu fiquei 10 anos nesse grupo, nessa estrada, fazendo shows convencionais, barzinhos. A gente chegou a gravar em vinil, a gente participou de um Festival e ficamos em segundo lugar, inclusive em uma casa chamada Estação do Samba, aqui pertinho e então, a gente gravou, fizemos parte de uma coletânea e gravamos uma faixa nesse disco, e quando estava quase estourando a gente desmanchou, basicamente por conflitos internos, porque cada um foi buscar os seus interesses.

Eu ao invés de seguir uma carreira solo, continuar, eu me desmotivei, fiquei 
chateada com o que aconteceu com o grupo e então eu fui me dedicar a uma coisa que eu já fazia, que era a educação.

Fui estudar, fazer cursos complementares, pós-graduação, fiz administração escolar, supervisão escolar, fui diretora de escola - até o ano passado fui diretora de escola, designada, porque mesmo concursada ainda não consegui me efetivar. Acabei então focando mais esses anos na educação.

Paralelamente a gente fez um trabalho que era chamado "The Teachers", nós éramos três professoras e fazíamos um trabalho em três vozes, mas de músicas em geral, não samba. MPB, música internacional. A gente era chamada nesse circuito da educação para fazer apresentações...

Fiquei então fora do circuito do samba, tive minha filha mais velha nesse meio tempo. E depois conheci o Samba da Vela

Pergunta: Como vocês ficaram sabendo do Samba da Vela?

Resposta: Mídia mesmo, e então viemos conhecer o Samba da Vela. Eu tenho uma veia mais de intérprete, componho muito pouco, quase nada, eu sou mais letrista, eu adoro interpretar, mas escrevo algumas coisas, tenho algumas parcerias com a minha irmã mesmo, com o Marcos Morais, com o Petróleo.

No Samba da Vela reacendeu essa chama de voltar a cantar samba e então retomei. Já conheci algumas pessoas de outros lugares. O Chapinha do Vai-Vai, o Paquera do Vai-Vai, o Nino Miau também, entre outros.

Mas é sempre importante lembrar que eu tenho uma trajetória de vivência de escola de samba, grupo, de ter vivido algumas coisas que me dá know how pra opinar, pontuar algumas coisas.

\section{Antonio Marcos da Silva (Marcos Morais), 28 anos, toca banjo}

Pergunta: Conte um pouco da história do Samba D'Elas.

Resposta: O lance do Samba D'Elas, eu entrei meio que de gaiato. Se não me engano a primeira apresentação delas foi na "Rua do Samba", alguma coisa assim, e logo depois elas se juntaram pra tocar no Samba da Vela, fazendo uma homenagem ao dia das mulheres, e aí rolou uma empatia muito grande, elas fizeram super bem e aí resolveram montar o Samba D'Elas, que a princípio ia ser só mulherada tocando. 
Pelo fato de eu conhecer as meninas e tal, e eu sempre gostei muito de tocar com mulher. Eu me sinto, como músico mais a vontade de tocar com a mulherada.

\section{Pergunta: Por quê?}

Resposta: Ah cara! Acho que por causa do clima, mais por causa do clima do que de qualquer outra coisa. Apesar de que tocar com a mulherada não é fácil, não é mesmo! Por causa do clima, do vocal da mulherada. Por que geralmente a mulher no samba, quando ela tem espaço, ela canta de verdade, não é igual à rapaziada, porque a rapaziada é um ou outro que canta, o resto fica no coro. A mulherada se você der espaço elas seguram o rojão.

Aí elas me fizeram o convite pra tá acompanhando e fazendo parte da roda. Tanto é que no começo, quando eu comecei a acompanhar as meninas aconteceu um fato engraçado, que a rapaziada falava assim: "Você é louco, tá tocando muito com a mulherada, aquele samba das meninas é muito ruim. Aquele samba é muito não sei o que...”. E não foi só dos homens que eu ouvi isso, ouvi de mulher também.

Hoje em dia, acontece de escutar: "Meu! Como é que faz pra tá tocando junto?”. Aí não é comigo, eu toco junto, faço parte da comunidade, mas não faço parte da diretoria. O lance da diretoria é só entre elas, mesmo.

Eu acho como homem, bacana ter uma comunidade fundada, dirigida e organizada pelas mulheres. O que eu acho bacana na comunidade do Samba D'Elas, é que não acontece uma coisa que acontece na maioria das comunidades que são formadas por homens, que é assim a mulherada não tem espaço, e isso é real, porque o samba infelizmente é machista, isso quem tá falando é um homem. $\mathrm{O}$ samba é machista e infelizmente é hipócrita.

\section{Pergunta: Por que hipócrita?}

Resposta: Porque o sambista prega muito uma coisa e faz outra, essa é a real. Apesar de só ter 28 anos, eu já vi muita coisa no samba pra chegar a essa conclusão. Infelizmente, é um dos ritmos brasileiros que mais entretém fácil e não é forte, e não tem o espaço que tem, por culpa do próprio sambista. Não é por culpa da mídia, das gravadoras, essa ladainha que todo mundo fala. Opinião minha, Marcos Morais falando, é culpa do próprio sambista mesmo.

Porque se o samba, principalmente o samba de São Paulo, fizesse o que acontece, por exemplo, no samba do Rio, a união que é, a união de verdade, sem hipocrisia, seria forte e de igual pra igual com o samba do Rio de Janeiro, que não deve em nada para o samba do Rio de Janeiro e pra samba de lugar nenhum.. 
Pergunta: Você acha que é mais desunido o samba de São Paulo?

Resposta: É mais hipócrita. Às vezes existe até união, mas assim, é eu, você e mais um. Tem um monte, tem 50 fazendo parte da panela, mas na hora do "pega pra capá", na hora de entra o money de verdade, na hora de se promover, é eu, você e mais um. Pô, mas todo mundo correu junto, mas não, é eu, você e mais um. $O$ resto que vier vai ter que trilhar o mesmo caminho, às vezes eu acho que isso errado porque enfraquece.

O Samba D'Elas tem essa diferença porque, eu como compositor e instrumentista, apesar de tocar com as meninas e tudo, elas me abrem o espaço e se fosse o contrário? Se fosse só homem e eu fosse a única mulher, eu não teria esse espaço. Se ao invés de Marcos Morais se eu fosse a Antonieta ou a Julieta, eu não teria este espaço se fosse o inverso.

Acho que elas montaram a comunidade do Samba D'Elas pelo fato delas freqüentarem as rodas de samba, as comunidades e terem pouco espaço.

A proliferação de comunidades que acontece, de uma certa forma é boa para o samba, sim. Mas por outra visão não é, porque são ramificações então tá se subdividindo. Eu acho que se fosse, de repente mais centralizado, em 5 ou 6 lugares, seria muito mais vantajoso, isso é um ponto de vista meu. Tem esse monte de comunidades espalhadas por São Paulo inteiro e também tem seu lado bom, divulga o samba, aparecem mais compositores. Mas na minha opinião, se fosse centralizado seria melhor, isso Marcos Morais falando.

Por isso que o Samba D'Elas tem essa vantagem, porque além de todas comporem, elas, cantam, tocam. E assim, não interessa se elas são ótimas instrumentistas, ou ótimas cantoras, ou ótimas compositoras nem nada, mas eu acho que elas fazem bem o papel de comunidade. Porque o que eu entendo de comunidade é todo mundo "fritar o peixe na mesma banha", como o sambista diz e não ter o lance da hipocrisia. Elas racham o pau? Racham o pau mesmo, lindo! Mas não fica aquele "disque que não me disque", o que elas têm pra falar cada um fala pra outra e acabou e o samba se fortalece por conta disso, porque não tem hipocrisia.

Então é um lugar bacana. Como eu disse no começo nego achava ruim por eu ser o único homem, tudo bem que agora têm o Serginho que faz o violão sete cordas.

Como samba, como manifestação do samba eu acho super válido, apesar de eu achar que se não fosse fechado pra mulher não teria aberto uma comunidade, $o$ Samba D'Elas por exemplo. 
Pergunta: Conte um pouco da sua história no samba em geral

Resposta: Minha história no samba começa, porque meu pai era músico, minha mãe era passista de Escola de Samba.

Pergunta: Seu pai era músico. Ele já era do músico do samba?

Resposta: Já, meu pai é falecido há um tempão. Eu nasci na zona norte especificamente na Brasilândia, e quando meu pai faleceu, eu tinha uns 3, 4 anos então eu não tenho muita lembrança e tal, então o que eu sei mais de pessoas que conviveram com ele. Meu pai tocava cavaquinho, tocava banjo, tocava violão, tocava bandolim, e minha mãe era passista de Escola de Samba. Minha mãe desfilou muito tempo no Rosas de ouro, até desfilou quando tava grávida de mim na barriga. Teve um rolo dela com o meu avô por conta disso.

Meus tios eram instrumentistas, mas assim, sambistas de final de semana, e aí eu cresci nesse meio. Depois eu fui embora pra Zona Sul, fui morar em Santo Amaro. Minha mãe casou de novo.

Durante um tempão eu lutei contra essa vertente do samba, eu escutava de tudo, eu escutava heavy metal, eu já andei patins, eu já andei de skate, eu já fiz o diabo a quatro, mas eu sempre fugi um pouco do samba por conta disso: o preconceito.

Chegou uma época que não teve muito pra onde correr, aí eu comecei a tocar instrumento de percussão...

Pergunta: Qual era sua idade quando você começou a entrar para o samba?

Resposta: Eu comecei a pular o muro da minha casa, pra ir para a roda de samba, com 13 anos. Esperava meu pai e minha mãe dormir e pulava o muro, tanto é que o muro da minha casa era baixinho, depois meu pai aumentou o muro, de repente por que ele sacou que eu fugia. Eu pulava o muro e ia para um terreiro que às quartas feiras rolava samba nesse terreiro. Eu ia e ficava todo encantado com aquele estilo de fazer samba, aquela malandragem toda e eu era o único moleque.

Pergunta: Onde era esse terreiro?

Resposta: Era no Jardim Ângela, ali perto da minha casa mesmo. Rolava de madrugada e era só o pessoal da velha guarda, e acho que é por isso que eu tenho essa paixão pela velha guarda e esse negócio de gostar do samba mais tradicional vem daí. Eu comecei a ir com 13 anos, mas a tocar, comecei com 15, 
16 anos a tocar instrumentos de percussão, tamborim, reco-reco.

Por conta de um show que eu fui do Fundo de Quintal, eu me apaixonei pelo banjo, porque eu fiquei do lado da caixa do Arlindo, fiquei vendo ele tocando banjo, então eu me apaixonei pelo banjo.

Eu achava que instrumento de corda qualquer um tocava, aí eu comprei meu primeiro cavaco pensando: "Amanhã eu já saio tocando". E aí eu vi que a coisa não toca desse jeito, aí eu tive que estudar, tive que escutar muita coisa e aprendi muita coisa com a malandragem do samba mais tradicional. Mas a minha vida musical começou a deslanchar mesmo depois que eu comecei ir para o Samba da Vela.

O Samba da Vela tem uma importância muito viva na minha vida. Quando eu comecei a freqüentar o Samba da Vela, por conta da minha vivência familiar e as minhas companhias, eu tava meio que desviando pra o caminho torto da vida e eu não tenho vergonha nenhuma de falar disso. Foi uma parte negra da minha vida, da minha história. Nunca fui preso, nunca usei drogas, nada disso, mas você começa a andar com certas pessoas.

Por morar na periferia, querendo ou não você fica com vontade de ter as coisas. Eu via, pô! Fulano trabalha o mês inteiro, e não consegue ter o que a malandragem, em uma semana tem, o que o cara ganha no final de semana. Dois dias, o cara tem que trabalhar às vezes 4,5 meses, então isso começou a me afastar um pouco do samba, meu olho começou a ficar grande mesmo.

Quando eu comecei ir para o Samba da Vela, por influência de um amigo meu chamado Ramon, porque ele chegou e disse: "Olha tem um samba que é assim, assim assado". Eu desacreditava que existia o Samba da Vela, eu pensava: "Meu, isso aí é papo". Mas desde a primeira segunda- feira que eu fui no Samba da Vela, e as vezes eu falo lá no Samba da Vela, que a Vela tem uma importância, não só como compositor, mas se hoje em dia eu to vivo, como ser humano, com 28 anos, pra tá dando essa entrevista e contando a história e participando do Samba D'Elas,o Samba da Vela tem uma importância na minha vida muito forte, como pessoa.

Eu comecei a freqüentar o Samba da Vela não só por gostar de samba, mas pela conduta que na época eu achava que era correta. Hoje em dia eu tenho minhas próprias convicções, discordo de muita coisa, mas isso não vem ao caso.

Essa importância fez com que eu começasse a enxergar a música de verdade como uma saída, então a partir desse momento eu comecei a de fato a entrar na música, aí eu fui estudar, comecei a comprar muito disco, CD, fui fazer muita pesquisa. 
Pergunta: Você chegou a estudar algum instrumento?

Resposta: Eu comecei a estudar cavaquinho, meu tio pagou as aulas, mas eu nunca gostei muito da parte teórica, eu achava e acho muito chato até hoje, apesar de saber que é necessário. Mas foi mais de olhar mesmo, porque eu queria tanto, tanto aprender que eu ia pras rodas de samba do pessoal da velha guarda $\mathrm{e}$ ficava de frente, mas assim "secando" o músico que estivesse tocando banjo ou cavaquinho, e quando chegava em casa eu tentava fazer igual.

Muitas vezes meu pai achava ruim e minha mãe também, minha família no começo era contra. Diziam: "Vai ser músico? Mais um músico!" Aquela história toda de que músico é vagabundo.

Então eu fui aprendendo, aprendendo, mas o que me ensinou mesmo foi à noite, quando eu caí pra noite, que eu comecei a entender como funciona o samba em si. Porque pra quem ta de fora, o samba simplesmente é sentar e tocar, mas os bastidores do samba é que fica o astral. Todo esse negócio da religião que tem no samba no samba é um negócio muito verdadeiro, tem gente que vem tocar, traz um pouco do candomblé, traz um pouco da mesa branca por exemplo.

Pergunta: Esse samba do terreiro que você freqüentava com 15, 16 anos tinha essa parte de religiosidade?

Resposta: É tinha porque, a não ser nos dias que rolava o samba, os outros dias era um terreiro de umbanda, então tinha toda a ligação.

Pergunta: Existe ainda esse terreiro?

Resposta: Não, não existe, hoje em dia é um supermercado onde era.

Mas pra mim foi muito importante pra ter essa história no samba, eu aprendi muito e hoje em dia eu sei as diferenças que tem no samba, samba de terreiro, samba de partido alto, samba-canção, samba-lenço, que hoje em dia é o samba de quadra, e o tradicional samba de terreiro.

Como ser humano, o samba teve toda essa importância na minha vida, essa trajetória. Hoje eu tenho 28 anos não vivo do samba, sobrevivo do samba, porque quem vive hoje de música no Brasil, principalmente de samba sobrevive e hoje em dia eu tenho uma filhinha de seis meses pra sustentar.

Então hoje em dia, eu encaro o samba não só mais como diversão, já faz uns 2, 3 anos que o samba literalmente é meu ganha-pão. Faz um tempão já e eu pretendo viver disso até quando deus permitir que eu tenha vida e saúde.

Voltando ao instrumento, eu fui desenvolvendo no cavaco pra poder tocar 
o banjo, porque o banjo sempre foi um instrumento muito caro, então eu não podia ter, então fui tocando cavaquinho até poder comprar um banjo que é o instrumento que eu mais gosto no samba, não me vejo tocando outro. Toco violão em casa pra compor, que é muito bom, mas meu instrumento que eu gosto muito e tenho uma ligação espiritual, aquele negócio todo é o banjo, não me vejo profissionalmente tocando outro instrumento.

Pergunta: Me fala agora como você conheceu as meninas

Resposta: No Samba da Vela, porque eu conheço a Cida, a Ana e a Bia, já do Samba da Vela, e eu as conheci quando estávamos gravando o CD da Graça Braga, que até saiu agora. Nós nos conhecemos no estúdio fazendo coro, porque o Magno e o Maurílio, pessoal do quinteto fez a produção, e como eu já tinha feito coro no CD da Vela, eu já vinha trabalhando como corista de estúdio. Por convite então dos meninos eu fui fazer o CD da Graça e conheci as meninas. As outras meninas eu conheci fazendo parte da comunidade.

Uma coisa eu falo, se eu não tivesse ido com a cara delas eu não estaria no Samba D'Elas, por que eu acho que acima de qualquer coisa você tem que ser um músico, um sambista verdadeiro, se você não se sente bem naquele terreiro, você não vai freqüentar, se você não se sente bem naquela roda, você não vai tocar. É o que falta no samba, menos hipocrisia e mais verdade.

E depois que elas fizeram esse trabalho específico para o dia internacional das mulheres, elas resolveram montar a comunidade. Antes de elas me chamarem elas já tinham falado: "Se der pra você ir", "Você tem algum problema em tocar com mulher?". Poxa eu particularmente não tenho nenhum problema em tocar com mulher, e eu disse: "Se pintar oportunidade eu to dentro!". Cá estou eu! Desde a terceira ou segunda quinta-feira que elas fizeram, comecei a tocar.

Comecei a tocar no cavaquinho, até pelo fato do banjo ser um instrumento mais agressivo e aí o cavaquinho por ser mais light, por conta do estilo delas Mas um dia eu trouxe o banjo e elas acharam que ficava legal e acharam que eu tinha que tocar banjo.

Eu toco com elas e não ganho nada, ninguém aqui ganha nada. Eu toco com elas, exclusivamente porque eu gosto. Primeiramente por amor ao samba, respeito o samba, depois eu gosto de tocar com elas por causa do clima que é legal, e eu me sinto num harém (risos), essa é a real. Às vezes tem quinta- feira que só tem eu de homem, então é o maior barato, e elas me dão espaço.

Eu tenho uma maneira de compor muito minha, então eu mamei muito na fonte do Paulinho da Viola, Candeia. A minha maneira de cantar e tal. Até um tempo atrás eu não cantava porque eu era tímido. Eu comecei a contar de tanto 
ouvir Roberto Ribeiro. Mas mesmo mamando muito nessas fontes eu adquiri a minha maneira de compor. Eu gosto muito dessa coisa de samba tradicional de São Paulo, essa coisa do batuque, essa maneira de compor mais melódica, isso é uma coisa minha.

Por conta disso, eu tenho alguns parceiros, o Petróleo do Samba de Vela, a própria Aparecida, a Ana. Tem uma música que eu vou tocar hoje que eu fiz com a Bia.

\section{Pergunta: Qual é o nome?}

Resposta: É "O amor", o nome da música. É a segunda parceria que eu faço com a Bia, mas é o primeiro samba que agente vai apresentar.

Eu acho que o samba tem que parar com essa hipocrisia, porque nenhum sambista quer ficar cantando samba a vida inteira e morrer pobre.

Pergunta: Você trabalha com mais alguma coisa?

Resposta: Não, eu vivo da música.

Pergunta: Você fazia o que antes?

Resposta: Eu já fiz de tudo. Já fui porteiro, já fui desentupidor de fossa de rua, já trabalhei no "Rapa" da prefeitura, apanhei muitos dos camelôs, já trabalhei de faxineiro em colégio, já fui inspetor de alunos, durante um tempão contra a vontade da minha mãe já trabalhei na feira.

Eu sempre costumei falar que eu sempre trabalhei com música e os outros trabalhos, era pra fugir da rotina.

Mas é difícil pra quem vive intensamente da música, ou sobrevive do samba principalmente, é difícil conciliar a noitada com o trabalho durante o dia. Por que o dia que é quando você tem pra dormir, você vai trabalhar, então, ou você vai trabalhar no trabalho convencional cansado, ou vai trabalhar no samba cansado. Um dos dois você vai cansado.

Voltando na maneira de compor. Da mesma forma que o Cartola e outros compositores falavam de amor, eu falo de amor da minha maneira, sem ser hipócrita, sabendo que infelizmente no Brasil o que vende é você falar de amor, não tem jeito. Você pode falar da história de quem for, mas o que faz com que você tenha uma sustentabilidade de dinheiro, financeira, é falando de amor.

Eu cheguei a seguinte conclusão, que eu posso muito bem falar de amor, usan- 
do o samba tradicional, sem cair no modismo e sem deturpar a cultura. Porque o que acontece muito hoje em dia é, o pessoal fala de amor, mas de uma forma deturpada, de uma forma que chega a ser vulgar, e isso é muito feio. O samba não precisa disso. Você pode muito bem falar do seu sentimento de uma forma clara, de uma forma gostosa. Você não precisa ser hipócrita e destruir a cultura.

Eu demorei um tempão para achar minha forma de compor, não minha fórmula do sucesso. Mas a minha forma de compor, porque eu acho que todo sambista tem uma forma única, ao ponto de você escutar e dizer: "Essa linhagem é do Marcos Morais", "Essa linhagem é do Samba D'Elas", "Essa linhagem é do Samba da Vela". E eu acho que o mais difícil do sambista, é adquirir a personalidade, adquirir uma forma sua de compor.

Como o estilo de compor "Rio de Janeiro" é muito impregnado na cultura do samba de São Paulo, às vezes sem perceber você acaba caindo na forma do Rio, mas se for pra fazer igual os caras do Rio, não precisa fazer, porque já tem o pessoal fazendo.

Eu então como compositor novo, chegando agora, tenho que fazer uma coisa... Também não posso sair da raiz, mas tenho que fazer uma coisa que ninguém fez, de uma forma que ninguém fez. Mas o samba também tem aquele negócio, se você sair muito da raiz, você cai no modismo, e aí entra em toda uma discussão, o que é modismo, o que não é modismo.

O fato de você tocar um samba tradicional, não impede de você cair no modismo. Tem muito sambista que hoje em dia é a bola da vez, que tá ganhando muito dinheiro, que faz um samba tradicional, mas um samba tradicional que vende, então há suas controvérsias do que realmente tem que ser feito.

Eu acho que a cultura tem que ser defendida sim, por que senão eu acho que o samba vai virar folclore, mas também não precisa ser hipócrita, quem quer viver da música sabe os caminhos e as dificuldades que são quando você segue uma coisa tradicional. Você pode fazer sucesso fazer o tradicional, sem ser modismo e sem ser muito, muito tradicional. Isso vai de cada um, essa é a minha maneira de ver as coisas.

Eu ainda não sei se um dia eu vou gravar um disco ou não. Eu não me vejo maduro hoje, quinta-feira, o suficiente pra fazer isso, um trabalhão meu, Marcos Morais, mas daqui uma semana, um mês eu posso me sentir pronto. Essa é minha trajetória. 


\section{Sandra Lima (Sandrinha), 48 anos, canta e compõe}

Pergunta: Conte um pouco da história da comunidade Samba D’Elas - Herança de Ciata.

Resposta: Na verdade quando eu cheguei, a comunidade já existia. O bar pertencia a uma amiga minha chamada Gê Manhosa e ela me fez o convite: "Sandrinha, vai lá pra você ver um grupo de mulheres que tocam, que cantam”, e ela sabe que eu gosto muito disso, que eu sou envolvida com isso.

$\mathrm{Eu}$, como quem não quer nada, resolvi dar uma passada lá pra dar uma olhada. Cheguei e me encantei!

Pergunta: Você não conhecia as meninas?

Resposta: Não. Só conhecia a Zanza e a Elisa que são do Samba da Tenda, que eu já tinha ido lá. Mas a Cida e a Ana Elisa, do Samba da Vela, eu ainda não conhecia. Eu fiquei espiando.

Então a Gê, essa minha amiga, antiga dona do bar ela falou: "Olha essa minha amiga, ela também canta, ela também compõe!” Aí me convidaram pra sentar na roda e de lá pra cá nunca mais levantei dessa roda.

Aí me envolvi, gostei. Vi que é um trabalho sério, que é um trabalho de valorização da mulher. Porque você vai às rodas de samba que tem por aí, até mesmo em comunidades, a maioria é homem que toca, que canta, e você pede a permissão pra você tocar um pandeiro, tocar um instrumento, eles não colocam uma credibilidade em você. Deve cutucar lá com o amigo: "Ah não, senão vai estragar o samba".

Mas não é bem assim, tem mulher que toca, tem mulher que toca muito bem, melhor que homem, é o que essa roda ta mostrando, a capacidade que nós temos de fazer um bom samba. Essa roda tai pra isso, pra abrir espaço pra mulher. Não é só pra mulher, é pra homem também que gosta de compor, que gosta de cantar, expor trabalho. Você pode ver que não é nenhum clube da Luluzinha, os Bolinhas também podem participar.

Pergunta: Você está há quanto tempo com elas?

Resposta: Eu cheguei dois meses depois que elas tinham inaugurado a roda, junho, julho. Fez um ano em junho que eu tô com elas. 
Pergunta: Me conta sua história de vida.

Resposta: Bom, sou paulistana, da gema. Nasci no bairro da Liberdade há 48 anos, não tenho vergonha de dizer minha idade. Tenho dois filhos, um casal, meu mais novo tem 18 e a mais velha, 23. E uma neta de 7 anos.

Pergunta: Algum deles é do samba?

Resposta: Meu filho é compositor, mas não do samba. Ele é um ótimo letrista, escreve muito bem, é poeta, mas não é envolvido em samba. Ele escreve, o negócio dele é escrever, fazer ritmo já não é com ele.

Às vezes a gente sente lá e faz umas parcerias, ele faz a letra, eu coloco o ritmo e aí dá samba. A gente aproveita o ensejo.

A minha vida é essa, trabalho. Sou secretária, trabalho no Instituto de Segurança Pública, desenvolvo um trabalho com o "Proerd", que é uma entidade da polícia militar, que cuida de crianças viciadas, largadas, que ninguém quer mais. É um projeto de bem estar da criança. A gente pega as crianças da rua e dá todo o suporte pedagógico, dá assistência médica. São viciados, então a gente faz um trabalho de desintoxicação. É duro, mas é gratificante. Agora em julho, a gente fez a formatura de 3 mil crianças, e eram crianças de rua pedindo na praça da Sé, largadas, usando drogas, roubando e nós conseguimos fazer a formatura de 3 mil crianças, foi muito gratificante, todo mundo chorou. Até os coronéis, todo mundo, não teve quem agüentasse. Porque ver o trabalho que a gente desenvolveu durante um ano, renovar a criança que ninguém, dava mais nada e você vê a criança progredir.

Nós temos vários parceiros que dão oportunidade para essas crianças. Dependendo da faixa etária, de 15 a 18 anos tem empresas que abrem as portas, dá emprego pra essas crianças, como aprendiz. A gente prepara a criança e manda pras empresas. Tem meninos que tão lá até hoje, trabalhando, sustentando a família, não estão mais na vida errada. É muito legal.

Pergunta: Agora, me fala como você entrou no samba.

Resposta: O samba é uma paixão, que existe dentro de mim. Quem saber em número de anos? Há uns trinta anos atrás, eu tinha 19 pra 20 anos, foi quando eu comecei a me envolver com esse mundo do samba.

Pergunta: Da tua família alguém era envolvido com samba?

Resposta: Meu pai era músico, meu avô também. Meu avô em minas e meu pai 
aqui em São Paulo. Meu pai era militar, ele ticava $\mathrm{m}$ bandas, bandas da polícia militar, ele era um músico que conhecia acordes, tocava muito bem, mas ele tocava metal.

Da minha família, eu sou a única mulher dos filhos. Tenho 5 irmãos homens, a única que saí por esse lado fui eu. Os outros são tudo certinho, casados, são pais de família, mas me apóiam.

Pergunta: Mas como você começou?

Resposta: Comecei assim, freqüentando roda de samba, que é minha paixão.

Pergunta: Você começou cantando?

Resposta: Teve um amigo meu, há muitos anos atrás que falou: "Tua voz parece um Colibri. Você precisa cantar, desenvolver esse lado". Aí comecei a participar mais, e de doze anos pra cá tenho feito muitos shows pela prefeitura de São Paulo, de Guarulhos, Campinas, Indaiatuba.

Pergunta: É um trabalho a parte do Samba D’Elas?

Resposta: Sim paralelo, é um trabalho meu. Muitas apresentações, pela coordenadoria do negro, que me chamam muito.

Pergunta: E é samba também?

Resposta: Lógico, samba raiz sempre. Só que nessa época eu era mais intérprete. Eu até mandava músicas minhas, mas eu mais interpretava músicas de outros cantores como: Dona Ivone Lara, Leci Brandão, Beth Carvalho, Nelson Cavaquinho, Cartola.

Ultimamente os shows que eu estou fazendo, ando tocando mais minhas do que deles. E taí, porque eu levo uma vida de cantora, fora o Samba D'Elas vai pra 13 anos. 13 anos que eu sou da night (risos).

Pergunta: Sandrinha, voltando a essa questão da resistência por parte dos homens. Você vê que com esse um ano de Samba D'Elas, você sente que a aceitação já começa a existir?

Resposta: Sim, existe uma grande aceitação, eles nos convidam bastante. A princípio eles não acreditam muito. Chamam porque a mídia mostra. 
Pergunta: E como você entende essa mídia? Como funciona essa comunicação entre as comunidades?

Resposta: Nós cantamos no Samba da Vela, pouquíssimas pessoas, um grupo de mulher sentou no Samba da Vela, cantou, no Samba da Tenda, na Maria Cursi, várias comunidades a gente já se apresentou. Então você pega credibilidade, porque os sambistas se encontram nas grandes rodas.

Pergunta: E o pessoal vai mais por bairro ou o pessoal vai até outras rodas mais longe?

Resposta: Vai sim. Eu já cantei, por exemplo, no Samba da Laje, mas não com o Samba D'Elas, já cantei sozinha. Mas o pessoal vai, porque é um mundo muito legal, porque você canta aqui hoje no Samba da Vela, todo mundo fica sabendo, vai no boca a boca. A gente coloca reportagem no Orkut também, a gente faz um auê, é automático.

Pergunta: Vocês têm site?

Resposta: Não, ainda não. Temos Orkut e e-mail também.

Pergunta: Eu vi que vocês saem também na Revista da Periferia.

Resposta: Saímos, a gente tem uma amiga que luta pela questão da mulher, da discriminação.

Pergunta: Ela é da revista?

Resposta: Sim, ela é editora chefe da revista. Eu cheguei e pedi pra ela. A princípio ela falou, "mas Sandrinha..." e eu disse, vai dar certo, coloca . Eu acredito no Samba D'Elas.

Ela colocou e agora ela que me lembra: "Sandrinha, você não vai mandar (risos)"?

Pergunta: Ela é jornalista?

Resposta: Ela ainda não se formou, está estudando pra jornalismo.

Ela faz parte de muitas Ongs de mulheres negras, é poetiza também, já escreveu alguns livros também. Ela é muito inteligente. 
Pergunta: Ela é do samba?

Resposta: Não.

Pergunta: Pra você, o que o Samba D’Elas te traz? O que você espera?

Resposta: Nossa, o dia que eu não venho aqui fazer minha apresentação eu fico doente. Eu fico muito ansiosa esperando chegar o dia, pra eu sentar nessa mesa e fazer meu trabalho.

Agora, o que eu espero é a valorização da mulher mesmo, dentro do samba, que não existe ainda, mas pode acreditar que vai passar a existir. Porque depois que o Samba D'Elas, chegou aí pra dar uma cutucada nesse meio, o pessoal tá olhando a gente com mais respeito.

As perspectivas são as melhores, se vier a fama, a gente segura a fama, senão vier a fama a gente segura também, não tem problema, tanto que a roda continue e porque é bom. A gente já está empregada pelo Corinthians, fazendo um samba lá uma vez por mês, o próximo agora é dia 16 de agosto. A gente canta em frente à lanchonete, o restaurante pra animar o povão.

Tem outros convites que a gente não pode nem falar ainda porque ainda não está acertado. Depois que você desligar o gravador, eu te falo (risos).

Tem muita coisa boa pro Samba D'Elas. Vou até me arriscar a falar pra você que tem até um show internacional pra gente fazer. Ainda ta em negociação. Mas vai fechar! Deus é pai, a gente merece, vai fechar!

5. Entrevista com Tais Zanelato (Thais), 26 anos, Tantã e vocal; Elisângela Simião (Zanza), 32 anos, pandeiro, compõe e canta; Elisa Aparecida Gondim Simião, (Elisa), 39 anos, cavaquinho e vocal

Pergunta: Zanza, me conte um pouco da história do Samba D’Elas.

Zanza: A gente se encontrou a primeira vez no Samba da Vela, em homenagem às mulheres, em 2008, no ano passado. Era uma homenagem, que eles organizaram pra homenagear as mulheres sambistas das comunidades.

Fomos convidadas eu e minha irmã Elisa, e como a gente conhecia a Thaís do bairro, convidamos a Thaís para participar, então fui eu, a Elisa e a Thaís. Chegamos lá conhecemos a Ana Elisa, a Cida e as meninas do Feitiço de Mulher, aí 
rolou uma simpatia logo de início, uma energia. A apresentação nossa foi super bacana, era pra cantar músicas inéditas porque lá tem as meninas do Samba da Vela.

Depois, no sábado, nós estávamos num evento na "Rua do Samba", onde eu e a Elisa fomos representar o Samba da Tenda, que é a comunidade que nós fazemos parte e a Ana e a Cida, foram representando o Samba da Vela.

Na hora que nós estávamos no palco para acompanhar cantoras, era a formação que iria acompanhar. A Ana e a Cida já cantaram e entraram com os instrumentos, e ficaram sentadas com a gente, naturalmente. Foi uma coisa que não foi combinada, aconteceu naturalmente. Rolou essa energia assim, automática.

No domingo ia ter o Samba da Tenda, e de última hora, nós mulheres da Tenda, organizamos um evento.

Pergunta: No mesmo final de semana?

Zanza: No mesmo, então a gente se encontrou na segunda, depois no sábado e no domingo a gente organizou uma roda que era pra homenagear as mulheres também, que era o mês das mulheres. Aí as meninas foram gentilmente conhecer a comunidade do Samba da Tenda, forma todas que participaram da roda da Vela.

Pergunta: E faz quanto tempo que vocês são do Samba da Tenda?

Zanza: Eu e a Elisa, faz 5 anos. 5 anos, né Elisa?

Elisa: 4 anos.

Zanza: A gente foi convidada para o Samba da Vela, porque antes, no início do Samba da Vela, nós fazíamos parte, de freqüentar, tudo. Porque antes, a gente tentou ter esse projeto no Samba da Vela, não no Samba da Vela, mas em um bar que o Chapinha tinha. A gente tentou ter uma linhagem desse projeto entre eu, a Elisa e a Flávia. A gente começou lá com a antiga esposa do Magno, a antiga esposa do Maurílio.

A gente organizava uma roda de samba feminina com o mesmo propósito, de a gente se encontrar e tal, só que não tinha compositoras. Oito anos depois a gente foi conhecer as meninas lá no Samba da Vela, então foi muito legal esse lance de estar revendo isso aí, foi bacana pra caramba.

E então nós começamos. Agente se encontrou numa terça ou numa quarta, num lugar central pra todo mundo, que era o Shopping D. Na primeira reunião eu 
lembro que estava: eu, a Ana Elisa, a Elisa, a Cida, uma compositora do Camisa a Rejane, tinha uma outra cantora, a Camila, a Dígena, a Thais também, tinha essa mulherada e que deu continuidade foram as pessoas que você entrevistou e os meninos.

Pergunta: Me conte sua história no samba antes do Samba D’Elas.

Elisa: Que bom, porque ela conta por mim e por ela, porque é a mesma,exatamente, somos irmãs, é a mesma.

Zanza: É só que com uma diferença, a minha história começa através dela, é legal isso. É bom que dá pra você aproveitar esse material.

Quando eu tinha 9 anos de idade, a Elisa começou com um grupo, um grupinho.Sabe grupo de samba de bairro?. Então, tinha um grupo feminino de samba em São Paulo que se tornou conhecido pra caramba, no estado, eles viajaram pra caramba, era chamado "Fora de Série", era um grupo aqui da Penha, da zona leste esse grupo. Tinha essas meninas e tinha meninas que tocavam em casa, informalmente.

Pergunta: Isso foi quando?

Elisa: 89.

Zanza: Acho que foi antes, seu cavaquinho é de 87.

Elisa: É 87.

Zanza: Aí a Elisa foi convidada pra fazer um teste de cavaquinho.

Pergunta: Ela já tocava?

Zanza: Não, ela tava começando a tocar. É que... É bom que você vá conhecer aqui a região. Aqui na Zona Leste, um dos fatos da região, não sei se devido a ter a Nenê de Vila Matilde, que é uma escola totalmente tradicional, conhecida no Brasil inteiro, a maioria das pessoas conhecem ou já ouviu falar pelo menos. Tem um histórico de samba, é muito forte a tradição da zona leste em termos de samba.

Aqui a gente tinha vários professores que davam aula de harmonia. Um deles, daqui da região da Ponte Rasa chamava Mestre Luciano, essa pessoa foi o professor da Elisa de cavaquinho. Quando ela chegou, ela tinha 17 anos, em 80 e 
ele falou: "veio um grupo aqui atrás de uma cavaquinista". Só que esse grupo, o Fora de Série, era um grupo de primas e irmãs, então moral da história, elas tinham integração já, elas já tocavam em festinha de família, todos sentavam direto. A Elisa então era muito iniciante para o grupo, e então as meninas desfizeram dela. $\mathrm{Na}$ verdade não desfizeram, não aceitaram, porque as meninas queriam uma pessoa que já tocasse.

Elisa: Era fraca e tal

Zanza: Era muito fraca, ela sabia tocar o que? Duas músicas, que era "Papai vadiou" e uma outra.

Aí o que aconteceu? Uma outra garota que estudava banjo, com esse mesmo professor falou: "vamos montar um grupo?", que era todo mundo iniciante. Eram duas irmãs e mais as meninas do bairro, mas esse grupo não decolou.

Pergunta: Qual era o nome?

Zanza: Ninfas do samba. Mas os ensaios era na minha casa, então eu era aquele cara que quando faltava a menina do pandeiro, eu segurava o pandeiro, faltava a menina que tocava tamborim, eu tinha saber que tocar pelo menos a condução do tamborim, então com nove anos eu aprendi a tocar percussão, com nove anos, e criança aprende rápido então desenvolveu rápido.

Depois essas meninas começaram a namorar, casaram, e a única pessoa que manteve o grupo foi a minha irmã. Entraram outras garotas, outras pessoas do bairro próximo e a gente começou a tocar na noite.

Pergunta: Elisa, você tinha alguém que tocava samba na família?

Elisa: Não, não tinha.

Pergunta: E como você se interessou por começar a tocar cavaquinho?

Elisa: Nossa, eu adorava o instrumento. Escutava um cavaquinho de longe e pensava: "Nossa, que instrumento bonito!", aí eu comecei a aprender, foi assim.

Pergunta: E vocês freqüentavam a Nenê da Vila Matilde?

Elisa: Sim, a gente ia, a gente desfilava. Eu sempre escutei samba. 
Zanza: Tinha muito essa influência musical de infância. A gente via partido alto e tal, e começa a treinar em casa. Eu sou grata a entrar no samba ao Luciano e à Elisa. À Elisa por ter me colocado no grupo, mas por ter aquela coisa de não querer andar com a irmã, mas nova no começo era difícil.

Elisa: Eu achava ela muito nova.

Zanza: Eu sou grata ao Luciano, porque ele chegou pra ela e disse: "Elisa, larga a mão, você tem a menina que toca aqui. Essas meninas não querem saber de samba, coloca ela". Aí a gente começou a fazer junto esse trabalho das Ninfas do Samba.

Eu lembro que o primeiro show grande que nós fizemos foi em uma casa chamada "Santana Samba", que hoje em dia acho que nem existe mais, lá na Cruzeiro do Sul.

Elisa: Nós tocamos um ano nesta casa, pra mais de 2 mil pessoas.

Pergunta: Era samba de raiz?

Resposta: Sim, éramos nós e mais umas 5 meninas. Era samba de raiz, depois dessa época é que começaram a lançar esses grupos, era tudo uma mesma fase. Era o início, por exemplo, do Katinguelê, do Art Popular, só que todos nós tocávamos samba de raiz, aí o pessoal depois entrou para a área comercial e mudou um pouco o estilo, mas todos tem formação de samba de raiz. Tem gente que fala: "Pagodeiro, não sei o que", mas não, se tiver que fazer um samba de raiz faz lindamente.

Então, a gente começou a tocar nesses lugares, começamos a tocar nas escolas de samba, porque nós tivemos um empresário chamado João Lee. A gente abria show de Zeca Pagodinho, de Fundo de Quintal, de Reinaldo, Eliana de Lima, nas festas que em São Paulo, hoje em dia não tem essas festas mais, mas na época o point eram as escolas de samba, então tinha a festa de Hawaí, Festa da Bateria, Festa do Samba-Enredo, era muita festa. A Sandrinha deve lembrar dessas festas (risos).

Elisa: E era muito isso de Rio de janeiro, era Zeca, Jovelina, Jorge Aragão. O pessoal vinha e a gente abria o show. A gente então começou a abrir shows em escolas de samba, em São Paulo, nova.

Pergunta: A idade de vocês qual era? 
Elisa: 17, 16, 19 e 18, era essa faixa. Dali a gente viajou muito com as Ninfas pra Franca, Campinas etc.

Pergunta: Quantos anos vocês ficaram com as "Ninfas"?

Zanza: Quatro anos, porque a minha outra fase foi final de ginásio e eu já tinha meus 14, 15 anos de idade. E então a gente começou a ter vida normal, trabalhar, estudar, finalizar os estudos, essa coisa toda, mas sempre tocando.

Nessa época o tocar não era tão profissional quanto antes. A gente tocava de vez em quando no sábado, daí há 3, 4 meses tocava em outro lugar, aí tinha meninas que às vezes eu ia, ou ela ia, como freelancer contratada pra fazer uma apresentação.

Então, a gente terminou o colegial, e agente tava trabalhando numa empresa. Você olha aí a nossa vida junto (risos), a gente tava trabalhando numa mesma empresa.

A Elisa, sem compromisso de estudar com ninguém, ela começou a estudar cavaquinho com o Biro do cavaco, estudar harmonia, aprofundar mais na parte harmônica.

Nessa época, abriram vagas para a ULM, a Universidade Livre de Música de São Paulo, ela foi e me chamou. A gente já não tinha mais compromisso musical. A gente trabalhava, estudava, tava na questão do hobby, então decidimos estudar música.

Na ULM nós conhecemos pessoas que mudaram a nossa vida, porque lá eu comecei a estudar outros ritmos. Lá eu comecei a estudar partitura, outros ritmos, outros instrumentos. Comecei a aprofundar aquela vivência de bar, de roda de samba e unir isso com a questão de teoria, de ritmos regionais, outras coisas. Comecei também a fazer cursos com outros instrumentistas e abrir o horizonte, saí um pouco daquele mundo só do samba. A gente ficou fora do samba uns dois anos, completamente, a gente fazia coisas completamente diferentes.

Por exemplo, eu tocava pandeiro de couro e a gente fazia com um catado de alunos a levada do maracatu, outras levadas, outras coisas que aconteciam, e não era samba. $\mathrm{O}$ que era samba assim era chorinho.

Elisa: Por outro lado eu também saí do samba e comecei completamente a estudar choro. Era um mundo pra mim diferente, porque a gente aqui na zona leste não tem muito esse acervo de choro, a gente não escuta muito choro. Hoje tem, mas naquela época não tinha. Comecei a fazer aula com um grupo de alunos e ela também fazia pratica de pandeiro com a gente. Acabou sempre se unindo. 
Zanza: Mas é engraçado, isso não acontece por que uma leva a outra.

Elisa: É o destino mesmo

Zanza: Acontece, não sei se é a seqüência de nome, aprova uma e quando vê aprova a outras.

Pergunta: Qual é a diferença de idade de vocês?

Zanza: Sete anos. Mas é sorte, por exemplo, ficha de emprego, me contrata e depois ela, ou ela e depois eu.

Pergunta: E vocês são em quantas irmãs?

Elisa: Somos em quatro, tem mais uma irmã e um irmão. Que não tocam.

Zanza: Voltando a ULM, lá a gente conheceu a Flávia. Da ULM a Flávia era a pessoa que curtia samba, só que no primeiro instante que ela viu a Elisa, ela teve aquela birra de mulher, foi aquela coisa, "perdi meu reinado de cavaquista da turma".

Elisa: Eu lembro que na época era muita gente, pra duas vagas de cavaquinho. Quando eu passei no teste, eu cheguei e ela me olhou com uma cara meio ruim assim. Eu vi e pensei: “Outra mulher!" Só tinha eu e ela, na ULM inteira era só a gente de mulher que tocava cavaquinho, além da professora, a Ana Cláudia.

E com o tempo a gente acabou pegando uma amizade legal, até hoje a gente está junta.

Zanza: Até hoje, graças a deus.

Elisa: E teve esse impacto do lance dela e no decorrer de conversar: "do que você gosta?", "ah! Eu gosto de samba assim, assado", que era a linhagem que a gente gostava que já não se ouvia mais. A Flávia era mais pro samba, então de conversar rolou afinidade de gosto musical.

Zanza: Na ULM não se estuda samba e sim chorinho. Chega um momento que se faz uma levada de samba em alguma coisa, mas o que você estuda tanto em instrumentos como cavaquinho, violão de sete, além da questão de harmonia, é choro, o mais próximo. Já na parte de percussão, eu fazia prática de chorinho com eles, mas o que eu estudava eram ritmos regionais, nesse período 
do curso.

A gente se conheceu, e logo uns 4, 5 meses depois, se iniciou no Samba da Vela de São Paulo, e tinha um dos alunos que era de Santo Amaro e falou "Vocês precisam ir no Samba da Vela".

Pergunta: Quem era esse aluno?

Resposta: Ele é de Santo Amaro, mas não era do Samba da Vela. A vista que a gente tinha do Samba da Vela, é o que se divulga até hoje, que é um samba que a Beth Carvalho freqüenta e tal, porque é essa a principal divulgação do boca a boca do Samba da Vela.

Pergunta: E ela vai?

Resposta: A Beth, quando ela ta em São Paulo ela vai. Acho que vai ainda. Paralelo a esse processo que entrou a questão do samba feminino foi nesse instante. A Ana Cláudia, professora de cavaquinho tinha um grupo chamado TPM e não tinha percussionista.

Elisa: Fora esse tinha as "Choronas".

Zanza: Esse grupo, As Choronas, existe até hoje. É um grupo de choro feminino. É ótimo! São 5 mulheres, a solista é flautista. Elas tocam no Brasil inteiro, é outro universo, um universo paralelo.

No TPM ela convidou, e eu fui pra ganhar um dinheirinho e tal. As meninas do TPM não eram mulheres de samba, não tinham histórico de vivência de samba, eram pessoas que estudaram música, então nós tínhamos uma maestrina, pessoas que se formaram em conservatório, mas que não tinham vivência de samba, aquilo que eu tinha vivido desde criança. Então fomos eu e a Flávia para essa função lá pro TPM.

A Ana Cláudia, como começou a estourar as choronas, aquela época já era lançamento e viagens. Porque um show de samba iniciante é mal remunerado, pelo menos a maioria, já no chorinho não. No chorinho é bem diferente a questão da remuneração pelos locais que as pessoas tocam, é um outro nível.

Elisa: A Ana Cláudia me indicou inicialmente para substituí-las quando ela tinha shows com o Choronas. Nessa época as duas já estavam, a Flávia e a Zanza, aí passou um tempo e ela viu que não dava mais pra conciliar e me indicou pra entrar de vez no TPM. 
Zanza: A gente era a banda, a gente não era a linha de frente do grupo. Então ficou assim, a formação do TPM antes eram 8 mulheres, eu sei que a última formação do TPM estávamos nós 3, tinha a vocalista, a violonista de sete cordas que era a Rosana Bergamasco, que dá aula ainda na ULM e tinha mais uma pessoa só. Mas lá no nosso passado a gente tinha uma mulher que tocava a percussão.

No decorrer dos trabalhos que começaram a rolar no TPM e agente começou a manter uma linhagem de samba, porque samba é assim, não adianta você querer começar a fazer o samba hoje. Você pode saber o nome de todos os compositores, saber a história, saber como começou, mas se você não sentir aquilo na veia não funciona. É meio complicado, ser sambista é igual ser Corintiano tem horas né!? (risos).

Pergunta: Olha, a primeira vez que eu vi vocês tocarem estava passando jogo do Corinthians e eu achei engraçado, todo mundo tocando aqui e vendo o jogo, aí o Corinthians fez gol, vocês jogaram os instrumentos pra cima...

Zanza: Sim! (risos). Foi no dia da mulher esse ano. Quase todo mundo é Corintiano na roda mesmo.

Mas ainda na época do TPM, a gente encontrou uma menina, que na época do Santana Samba, ela era pública e quase 10 anos depois quando encontramos chamamos ela pra tocar. Ela entrou para o TPM e aí a gente fechou uma percussão de sambista mesmo, então os convites começaram a ir mais pra esse lado.

Então a música do TPM era inédita, era ritmo de samba, só que a compositora por não ser de samba naquele momento, ela tinha uma linhagem de composição meio cômica, sátiras e tal. A harmonia do TPM era puro samba, mas as letras não, então eu acho que foi aí que não deu certo, porque no decorrer do TPM a gente fez um monte de coisas, televisão também, mas a gente tinha quatro sambistas natas no grupo, então a gente começou a levar o grupo para uma linhagem que não era natural das outras meninas. Foi aí que nós começamos a fazer coisas à parte.

Foi em decorrer disso tudo que nós fundamos o Primeiro Espaço Feminino de Samba, no Samba da Vela, que era a sede.

Pergunta: Quando?

Zanza: Foi em 2000, no começo da Vela. 
Elisa: Uns 5 meses depois. Ainda não era na casa de cultura, era num bar, o Ziriguidum, era o bar do Chapinha.

Pergunta: Era então junto com o Samba da Vela?

Zanza: Junto, mas o Samba da Vela era de segunda e o nosso era de domingo, quinzenalmente.

$\mathrm{O}$ cenário era o seguinte: a gente sempre teve mulheres cantoras, mas as mulheres que era instrumentistas na época, em evidência, éramos nós, a formação instrumental do TPM, que era Eu, a Elisa, a Flávia, tinha também as esposas dos meninos do Samba da Vela e tinha também umas meninas de um grupo chamado Samba pras Moças, que eram instrumentistas também.

Então pra gente se encontrar, porque todo mundo vivia de música nesse momento, no tempo da ULM e então o TPM a gente não trabalhava mais formalmente, a gente só vivia de música, só que a gente não tinha tempo para o lazer, tempo de se reunir informal, tirar um barato, por conta disso, a gente começou a se reunir.

A gente entrou em contato como Chapinha, pedindo um espaço pra gente se reunir e organizar isso aí, só que fluiu de tal forma que as pessoas começaram a ir e era fantástico aquilo. Só que a gente não tinha uma qualidade vocal, porque todo mundo era instrumentista. Todo mundo só tocava, não tinha compositora. Eu vim começar a compor depois de um mês por aí, mas mesmo assim eu não compunha como hoje. A gente não tinha compositoras na roda, nem cantoras, $o$ que a gente tinha eram mulheres que tocavam.

Um dia a Beth chegou lá e levou revista, foi o pessoal do Multishow (canal por assinatura), foi uma coisa legal porque virou erre fórum mesmo porque foi bem nesse boom de comunidades. Foi logo quando estavam surgindo ali, por exemplo, a Vela já tava com seu alicerce pronto de 5, 6 meses, tava a gente, tava o pessoal do Morro das Pedras, tava surgindo tudo junto.

Tanto que tem uma matéria do Estado de São Paulo ou Folha de São Paulo, não me lembro que mostra as três comunidades. Éramos nós, mulheres, o Morro das Pedras, e o Samba da Vela, tudo surgindo junto, nesse boom de comunidade.

Aí passou cada um com seus trabalhos a parte e não dava pra continuar, porque era de domingo e quinzenal. Começou a desanimar, mas se você perguntar pra mim porque acabou o projeto, ninguém sabe.

Elisa: Ninguém sabe. 
Zanza: Porque não foi briga, não foi localização, porque a gente da leste a gente se locomovia pra chegar lá, às vezes deixava de almoçar até, por que é longe.

Elisa: Outro dia, eu tava no bar do Paquera, e o Magno me fez essa pergunta: "Porque acabou o projeto feminino?". Não sei, porque tinha um movimento legal.

Também tinha o TPM, que a gente tocava profissionalmente e as meninas também tinham outros compromissos e é muito difícil você manter ali, quinzenalmente, não é fácil não.

Pergunta: Mas e então vocês conversaram e decidiram acabar?

Elisa: Não, não teve essa conversa. Foi indo e acabou de repente.

Zanza: Foi igual namoro, aquilo "amanhã, a gente se liga", aí ninguém se liga, acabou.

Depois disso outras coisas começaram a surgir, na vida, eu comecei a fazer faculdade, comecei a namorar. Eu nunca tinha namorado antes, comecei a namorar.

Voltando ao TPM, o TPM caiu naquela lenda de fazer uma linhagem mais comercial, que não tinha nada a ver conosco. Houve propostas de a gente pintar o cabelo, mudar o nariz, magra eu já era, apesar de que pra entrar no TPM eu já tive que emagrecer bastante. Coisas que fugiam do samba.

Pergunta: E essas propostas vinham de quem?

Zanza: Do próprio empresário, a gente tinha um empresário, tanto que eu fiz um samba por causa disso. É na época eu já compunha mesmo. O samba era mais ou menos assim:

"Chega de papo furado, o samba que faço merece respeito
Que vem do peito, não há dinheiro que possa pagar o meu talento
Vem da veia, e incendeia, quem nele ficar, quem é bamba sempre resiste
Não insiste em querer me comprar, quem não conhece da arte pode parar
Por favor, se cale musicalidade em primeiro lugar
Andam fazendo de tudo pra ver se eu mudo o meu pensamento
Qualidade zero, vulgaridade ao extremo
Essa roda (feminina) é pra quem acredita no potencial
De quem veste a camisa do samba e quer ver valor musical”

Porque existia, desde a roupa, a roupa que era comum, era pra gente começar a colocar uma roupa mais escandalosa, para focar mesmo o produto feminino e 
não o produto samba, o ser sambista.

Isso chocou muito e com essas ações a gente saiu do TPM. A primeira que saiu foi a Flávia, depois a Elisa. A Paula ainda continuou mais um pouco e também depois acabou. Porque o que era vendido era o samba do TPM, e saiu a base do TPM musicalmente. As meninas eram todas com maior cultura musical que a gente, a cultura musical delas era excelente. Até hoje acredito que é bem mais evoluída que a minha cultura. Só que a cultura que a gente tinha da força de roda de samba, de boteco, de samba, nada compra isso, então acabou o grupo, a gente saiu e acabou o grupo.

Aí fizemos uns dois anos coisas normais, atividades normais, começamos a trabalhar; eu entrei pra área de Call Center, virei operadora de telemarketing, depois virei supervisora, concluí a faculdade, sou formada em Administração de Empresas e comecei a namorar.

Um belo dia surgiu o convite pra ir no Samba da Tenda e aí eu já compunha, escrevia em casa, mas eu não tava cantando. Mas é sempre assim, você vai em um samba, alguém lembra de você e chama, você canta um samba, uma música e aí a gente apareceu no Samba da Tenda, conta aí Elisa.

Elisa: Era no bar do Joel, em São Miguel, Vila Curucao. Chegamos lá era um botequinho, uma roda de samba de compositores. Eu tava totalmente fora do samba e fazia uns 2, 3 anos que eu não pegava no cavaquinho, aí eu cheguei nos meninos e disse: "será que posso vir aqui pra de repente pegar". Alguns sambas que eu nunca tinha escutado super antigos. Eles toparam e eu fui indo com o cavaquinho desligado pra acompanhar, eu fui indo, 1 mês, 2 meses, 3 meses eu e ela, como sempre. Depois de uns três meses, entramos definitivamente no Samba da Tenda.

Zanza: Aí veio o aniversário, tem que contar do aniversário.

Elisa: É o samba da tenda tava saindo di boteco pra ir para um projeto cultural, que é um CDC.

Pergunta: Existiam mulheres no Samba da Tenda?

Elisa: Não, imagina!Não tinha nenhuma mulher. Era bem escondido São Miguel Paulista.

Zanza: Pensa em uma rua sem saída...

Elisa: Sem saída, um boteco freqüentado por homens. 
Zanza: As mulheres que iam eram mulheres ali da vizinhança, ou mulheres que gostavam muito do samba.

Elisa: Mas era boteco mesmo, não era boteco família, bem de bairro mesmo. Era o copo sujo, o banheiro então nem se fala.

Zanza: E tinha uma batida de milho. Eu tomava uns 2 litros de batida

Elisa: O Joel, dono do bar sempre recebia a gente muito bem.

Aí me chamaram pra conhecer o CDC, aí eu fui lá, acho que fui uma das primeiras, eu era uma das mais novas, mas fui lá conhecer, peguei o carro e desci e quando eu vi, que lugar maravilhoso.

\section{Pergunta: O que é o CDC?}

Zanza: CDC significa clube da comunidade, aí construíram um Clube da Comunidade no Jardim São Vicente, chamado CDC Tite Setubal e então eles conseguiram, algumas pessoas da Tenda, realizar o Samba lá, sair do bar do Joel e ir pra lá. O Joel já ia fechar o bar e não tinha onde tocar a Tenda, porque lá eles já estavam há uns 2, 3 anos. A Tenda vai fazer 8 anos já Eles já estavam juntos antes da gente há uns 3, 4 anos e a gente chegou há 4 anos.

Pergunta: Nessa época não tinha ainda o nome de Samba da Tenda?

Elisa: Como Samba da Tenda tava começando a ficar conhecido. Era Samba da Tenda porque era debaixo de uma tenda, pra acolher do frio, da chuva, do sol.

Só que, Tinha um fluxo de pessoas? Até tinha um fluxo de pessoas que iam. Cantavas se músicas inéditas? Cantava se, mas era aquela coisa de bairro, era meio que fechado.

Zanza: Pra você ir lá, tinha que alguém localizar e te explicar, porque era numa rua sem saída e naquelas ruas de bairro, de vila, aquelas que pra chegar você quebra aqui, vira ali. Então eles tiveram essa oportunidade de ir para o CDC.

Nessa época tinha entrado um componente, uns 6 meses antes da gente, porque isso que a gente ta falando foi em Janeiro que a gente começou a freqüentar, mas era mais como freqüentadora, curtindo, fora da roda e senta e de vez em quando canta o samba. Como freqüentadora a gente ficou então uns 5, 6 meses.

Quando tava surgindo o aniversário, um cara que hoje é o vice - presidente, o 
Lão Gomes, tocou a campainha de casa e falou, com essas palavras: "Gente, eu to vendo que vocês são esforçadas, o pessoal é muito assim..."

Porque como era samba de vila, a proposta dos meninos era o que? Subir para o samba de manhã, comer um pastel na feira, faz uma batucada, almoça, às vezes nem almoça e rever os amigos, então não era aquela coisa organizada. E o Lão queria organizar uma festa, e disse que precisava da nossa ajuda e perguntou se a gente queria ir nessa luta com ele. Como a gente gostou da comunidade, a gente começou. Então era aquele trabalho de vender rifa, de não sei o que... Então duas mulheres entrando na roda, nessa parte de organização, começou a se organizar.

Aí foi quando a gente migrou pro CDC, nessa migração pro CDC logo em seguida foi o aniversário. A gente então correu atrás de coisas pra comprar o bolo, sabe assim? De comunidade, porque o bolo da tenda são 5 metros, até hoje são 5 metros.

Então a gente começou a organizar, levamos algumas coisas de experiências nossas, aprendemos coisas demais com eles.

Uma das maiores mudanças que a gente fez na Tenda, que foi horrível falar isso para um bando de 20 anos, que a gente quase "apanhou" (risos), foi em uma reunião que a gente sugeriu que se parasse de beber na roda.

Então a gente criou um manto e foi sugerido e a partir daquele dia proibido que se bebesse na roda. Então a gente nunca mais bebeu na roda, mas a gente ouviu pra caramba: "A vocês ficaram loucas?" e não sei o que, mas aos poucos foram aderindo.

Até hoje se você for na Tenda e sentar na roda, por algum motivo, nunca coloque um copo de cerveja em cima da mesa.

Elisa: $O$ pessoal bebe, mas não põe o copo na mesa, coloca no chão.

Zanza: Com isso começou a mudar um pouco, começou a ir mais mulheres porque o ambiente é melhor, o próprio ambiente físico é melhor. Começou a ir mais crianças então não dava mais pra gente continuar bebendo um monte. Não dava pra eu continuar bebendo quase 2 litros de batida de milho.

Elisa: É um público maior e focado, muito familiar. A gente não queria, por exemplo, quando a gente batia algumas fotos na mesa tinha um monte de bebidas e ficava feio. Hoje você pode ir qualquer dia que a mesa ta limpinha, nem água a gente põe na mesa, nem cigarro. $\mathrm{E}$ agora o pessoal bebe mais de boa.

Zanza: E assim começou a ir um público mais família. As pessoas que eram da 
comunidade já iam, mas o fato de mudar o local expandiu, mudou o público e hoje é rotativo. Hoje em média passam, por quinzena, na Tenda em média 400, 500 pessoas, quando está muito vazio é de 150 a 200 pessoas. Como o espaço é pequeno, dá impressão que tem trinta, mas quando a gente conta é essa média. No último aniversário nosso tinham 1.100 pessoas.

Pergunta: $\mathrm{O}$ espaço tem algum vínculo com prefeitura ou instituição?

Zanza: Não, ele não tem nenhum subsídio, nada.

Elisa: O terreno é da prefeitura, e o Tite Setúbal, que é um projeto do Itaú, construiu lá pra fazer um pólo cultural, a Fundação Tite Setúbal, mas não tem nada a ver, não dão nenhum subsídio pra gente, nada. Lá existem cursos pra garotos 13 anos.

Por ser um espaço da comunidade, a gente faz um samba pra comunidade, não é cobrado nada pra entrar e a gente faz lá como voluntária.

Zanza: Aí tem a cantina que é da Dona Júlia e da Lia, elas arrendam do clube. Elas que vendem a água, a cerveja, a alimentação, mas não tem a ver com a Fundação em si.

Depois que a Tenda entrou par esse espaço aí começou a organizar a documentação, e foi feito o estatuto, começou a entrar na parte da legalidade, de nome e tal, e então fazendo esse trabalho junto, montamos uma diretoria. Então além de musicistas, nós somos parte da diretoria da Tenda. Ela é a primeira secretária e eu sou a primeira tesoureira e temos o nosso presidente e vice-presidente, esse é o corpo executivo da comunidade.

É um espaço que se você pensar, você que está fazendo um trabalho sobre mulheres, você vê a resistência que há pra mulher, em qualquer área, ainda mais na questão do samba, e rola vários bracinhos. Da região, da etnia, da raça, vários bracinhos. Então a gente conquistou, na comunidade, um espaço que além de ser musicista, fazer parte da diretoria, de ta junto nas decisões, são votações e eu acho fantástico.

Desse período com a Tenda, foi que o Chapinha convidou a gente para o evento do dia das mulheres, que como eu disse, foi onde nós conhecemos as meninas e começou o Samba D’Elas.

Pergunta: Com relação à atuação das mulheres, tirando essa parte do preconceito, tem alguma coisa a mais que você acha importante acrescentar?

Resposta: Tem uma coisa, é como a Sandrinha diz: "A sua educação é que vai 
determinar a minha educação", vamos colocar a questão do preconceito, eu u particularmente nunca passei por preconceito. Por quê? Primeiro, porque eu comecei a tocar nova e fica aquela coisa, menina novinha tocando, engraçadinha etc, e também nessa de tocar aqui e ali, você acaba se tornando um rosto um pouco conhecido.

Como também a minha função sempre foi tocar, quem me ensinou a tocar sempre disse, "você jamais peça um instrumento para uma pessoa, se você na toca igual ou melhor que aquela pessoa". Por isso eu nunca tive esse problema de sentar numa roda de samba e alguém tirar o instrumento da minha mão, porque eu sempre sabia onde entrar.

Mas acontece com a gente. Às vezes a gente ta tocando, na própria Comunidade do Samba da Tenda, quando chega uma mulher lá e pede pra tocar, a tendência da mulher é vir até mim, porque são 15 homens e isso intimida. E então quando chega uma mulher e pede pra tocar, me dá vontade de beijar, de abraçar, e logo eu falo, "senta, senta!", mas aparece cada coisa que às vezes você pensa, é por isso que tem mulher que não tem espaço no samba.

Às vezes aparece mulher pra tocar pandeiro no Samba da Tenda, que é um samba que não é microfonado, não tem microfone nos instrumentos, com uma unha enorme, então como essa mulher vai tocar, se nem as unhas ela corta pra tocar pandeiro.

E aí quando vem alguém que toca pra caramba e pede pra um dos meninos já fica aquela dúvida, que é o pré-conceito, só que isso acontece com todo mundo inclusive com os homens, só que quando é mulher a mulher fica mais visada, porque é menos mulher que pede.

Elisa: Eu tive preconceito por ser branca, não por ser mulher. Comigo é diferente porque quem toca cavaquinho, é ciumento com o instrumento, é caro e você não gosta de emprestar pra qualquer pessoa, essa é a realidade, muita gente não gosta. Quando você pede o cavaquinho, é porque você toca, pelo menos o básico você tem que saber.

E de repente você pede e o cara diz: "mas você?" E não é por que eu sou mulher, a maioria das vezes que eu passei por isso é porque eu era branca, muitas vezes eu já passei por isso. Às vezes eu tinha que ter alguém conhecido pra eu sentar na roda, acontecia, ao eu sentava na roda e não saía mais. Mas isso é coisa passada, no comecinho mesmo eram poucas mulheres que tocavam cavaquinho e branca então...

Pergunta: E você vê mudanças na questão de preconceito com pessoas brancas 
no samba?

Resposta: Eu acho que sim, eu não consigo vincular mais isso, porque eu vejo muita gente branca no samba hoje. Eu acho que mudou muito até. O preconceito ainda tem um pouco, mas o samba é maior que isso.

Pergunta: E como vocês se conheceram (Thaís)

Elisa: Eu e a Thaís, a gente nada na mesma academia, eu estava conversando no banheiro não sei com quem de música e ela falou que tocava, e nós somos praticamente do mesmo bairro, eu conheço quase todo mundo, e aí ela começou a falar às pessoas que ela tocava, nomes que eu conheço e eu pensei legal. Então eu convidei ela pra ir no meu aniversário na Tenda, ela foi lá sentou na roda, tocou e aí fechou o trio! Então a gente chamou ela também pra participar no evento do Samba da Vela. De cara a gente conheceu as meninas da Vela.

No começo a gente não se conhecia direito, era meio formal, daí a gente começou a pegar amizade e ta até hoje. Foi tudo muito rápido, sabe quando a energia bate. Sabe a gente não tem muito tempo pra perder.

Pergunta: Me fale um pouco da vida fora do samba.

Elisa: Eu sou vendedora, trabalhei na área de vendas desde nova. Sou da área de consórcios, de crédito imobiliário, mas já trabalhei vendendo vários produtos, hoje eu trabalho com vendas na área de cosméticos, autônoma, um bico mesmo. Nasci aqui em São Paulo, na Penha, mas logo fomos pro Jardim Nordeste, metrô Arthur Alvim.

Thaís: Eu sou enfermeira, dou aula de enfermagem também e sou funcionária pública, concilio, dou aula geralmente à noite.

Zanza: Atualmente eu faço uns bicos, com vendas na área de cosméticos. No momento eu não to procurando nada fixo, porque fica difícil conciliar, tem o CD da Tenda o projeto do Samba D'Elas. Vou te contar uma coisa engraçada que aconteceu. Acho que eu fiquei tão preocupada com essas questões musicais que estão pra acontecer, que foi um pensamento, olha: fui chamada pra um emprego, aí eu velei todos os meus documentos, fiz o exame médico, tudo que tinha que fazer e me mandaram embora, eu nem comecei a trabalhar. O meu pensamento cortou o trabalho. Sabe onde era pra trabalhar? Na TAM, salário excelente, só que eram 12 horas por dia em escala 6 por 1. Aí eu firmei o pensamento pra Deus, pra Cosme e Damião, o qual eu sou devotada pra que 
a melhor coisa acontecesse e aconteceu isso.

Pergunta: Thaís e sua história no Samba?

Thais: A minha história, perto da delas é bem rapidinha. A minha história é parecida com a da Zanza. Minhas irmãs e minhas primas começaram com aquele negócio de "vamos montar um grupo".

Pergunta: De samba?

Thaís: De samba, aí começaram a estudar, a fazer aula. Eu escutava samba desde pequena, minha mãe e meu pai escutavam. Minhas irmãs freqüentavam escola de samba, eu não porque eu era muito nova, eu tinha 11, 12 anos.

Então elas começaram a ensaiar aqui em casa, e eu ficava só no cantinho olhando. Eu me sentia renegada, porque quando eu chegava perto todo mundo brigava comigo, "sai daqui". Elas tocavam e eu ficava só olhando, quando elas saiam eu pegava o instrumento e ficava tocando sozinha.

Elas tocavam muito na zona sul, abriam shows também, do Exaltasamba e outros grupos conhecidos.

Pergunta: Como era o nome do grupo?

Thaís: Ajexá, no início era Ijexá, mas como o povo não entendia e falava Ajexá, ficou Ajexá.

Um dia a menina do Tantã faltou e deu desespero nas meninas e elas conversando: "O que a gente faz? Quem a gente põe no lugar?" e eu disse: "eu toco". Ninguém acreditou, porque nunca ninguém tinha me visto tocar, elas não deixavam e eu também tinha vergonha.

Aí eu comecei a tocar e elas não acreditaram, aí a menina nunca mais voltou e eu fiquei no lugar. Mas tinha todo aquele processo, porque elas iam tocar na noite e eu tinha 12 anos e minha mãe tinha que ir me acompanhar. E então foi aquela coisa, uma casou, outra engravidou, outra ficou noiva e foi acabando. Ficamos 7 anos e a última formação já estava mais para o MPB.

Nessa época a gente recebeu uma proposta de um Cônsul da Colômbia, super interessado no nosso trabalho, tocamos na casa dele, veio o pessoal da Sony, queriam que a gente gravasse o $\mathrm{CD}$, nosso produtor também. Eis que um dia antes do show veio a proposta da roupa que a gente ia usar no show. Era uma roupa de coelhinha. Eu não quis nem ver a roupa e fomos embora na mesma hora. 
Depois disso o noivo de uma não achou legal e ela saiu, aí outra desistiu e foi acabando, até que eu saí também.

Mais tarde eu fui tocar com um grupo de homens, mas não deu certo por causa do horário do meu trabalho e faculdade também. Era samba também, tinha até os meninos do Jardim Nordeste. $\mathrm{E}$ aí eu parei por que eu não conseguia mais conciliar com a faculdade e o trabalho.

Depois que eu me formei aí eu conheci as meninas e começou tudo de novo. Eu achava que nem ia voltar a tocar, eu passei a tocar mais por hobby, em uma roda ou outra. Mas quando surgiu a proposta do Samba D'Elas eu me empolguei e pensei agora vai ser bom, e até hoje graças a deus ta dando certo.

Pergunta: E qual é a sua pretensão dentro do Samba D’Elas?

Thais: Nossa, eu nem pensava mais em tocar, mas depois que eu entrei pro Samba D'Elas foi tudo muito rápido. Apareceram várias propostas e um monte de coisas, não sei, mas eu espero que dê certo, que a gente firme mesmo e seria bom até agregar mais mulheres, porque uma comunidade feminina seria muito bom que aparecessem mais mulheres pra tocar com agente, o que é muito difícil, mas eu to empolgada sim.

Elisa: Eu já pensei várias vezes em parar de tocar

\section{Pergunta: Por quê?}

Elisa: Toda vez que acaba um grupo eu penso "ah não quero mais saber de tocar com mulher, chega to cansada", aí aparece uma coisa, aparece outra...

Mas eu penso porque trabalhar com mulher não é fácil não, imagina todo mundo na TPM. Cada uma tem sua criação, seu gênio e coisa e tal. É que nem namoro, que você começa a conviver muito com a pessoa e você aprende a respeitar, mas não pense que é mil maravilhas, a gente discute, a gente briga, a gente xinga, discorda, a gente as vezes não concorda com tudo, principalmente musicalmente. E tem isso da mulher, eu mesma tenho uma TPM insuportável.

Zanza: Olha, lidar com mulher já é complicado, só que no Samba D'Elas todas nós já temos um perfil de liderança nato e todas nós temos vivência diferentes e a única que é menina ainda é a Bia. Então pra qualquer uma de nós receber ordem da outra é uma coisa muito complicada.

Pergunta: E como vocês resolvem? 
Elisa: A gente não resolve, a gente quebra o pau, aí você imagina.

Thais: Eu e a Sandrinha a gente dá uma rasgadinha de vez em quando, mas a gente a inda segura, agora elas falam na lata, não tão nem aí se vai ofender ou não, fala mesmo (risos).

Elisa: Eu falo mesmo, acho que principalmente quando a gente convive em muita mulher, não posso deixar pra amanhã, tem que falar hoje, "Fulana você não tocou legal, fulana você desafinou hoje", tem que ser falado. Eu não vou ser chata com uma pessoa que eu não tenho intimidade.

O lado bom dessa mulherada junto é o talento, isso supera qualquer coisa, qualquer atrito, qualquer coisa. A soma das vivências de todas e no momento certo, deus sabe o que faz.

Thais: Eu acho que esse tipo de atrito é natural em grupo de pessoas.

Elisa: A maioria tem mais de 30 anos, são mulheres vividas, todas têm opinião própria. 
MULHERES NAS COMUNIDADES DE SAMBA TRADICIONAL: LIDERANÇA E LUTA RESSIGNIFICADAS

\section{APÊNDICE}

Imagens da Revista "Agenda Cultural da Periferia"

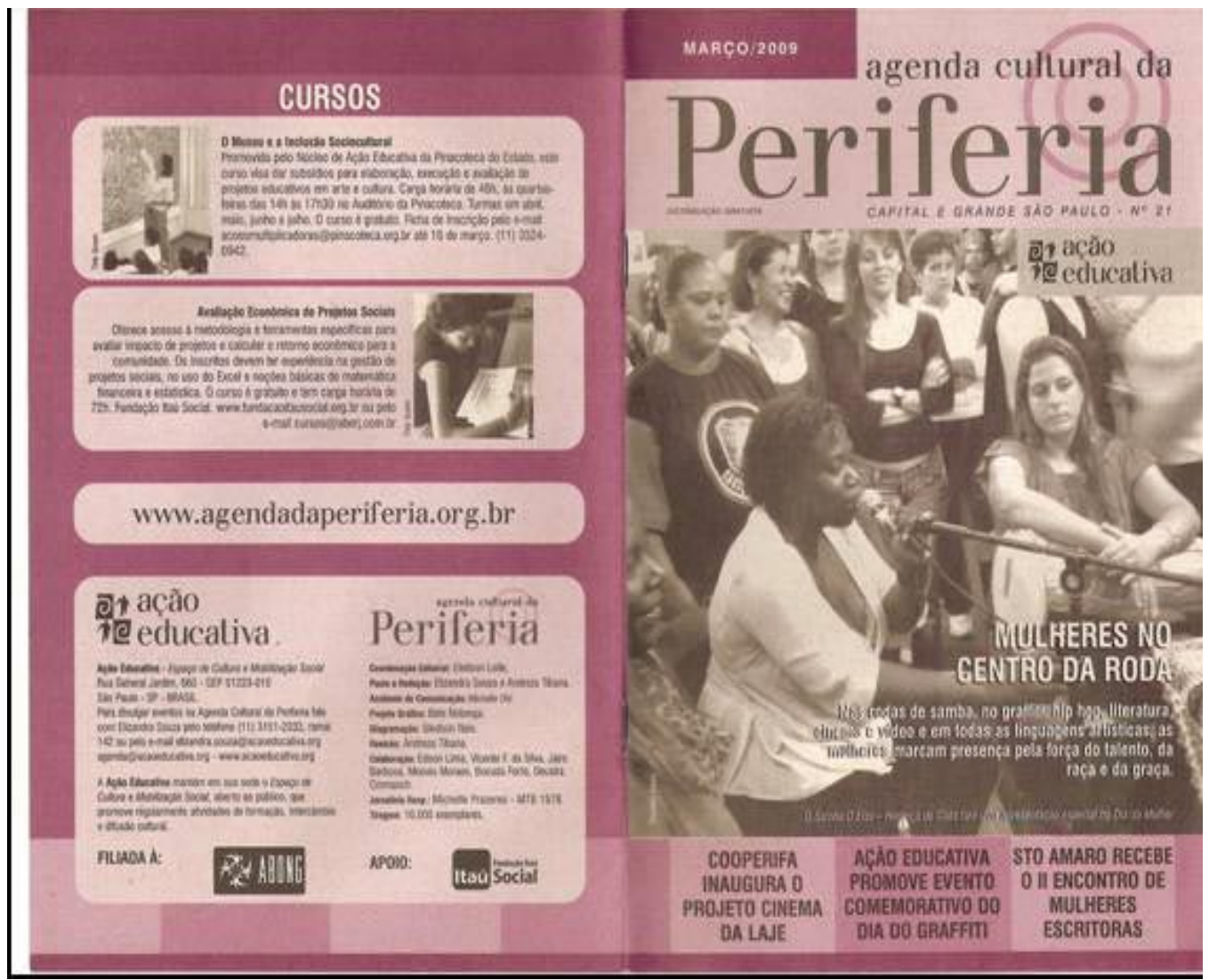


MULHERES NAS COMUNIDADES DE SAMBA TRADICIONAL:

LIDERANÇA E LUTA RESSIGNIFICADAS
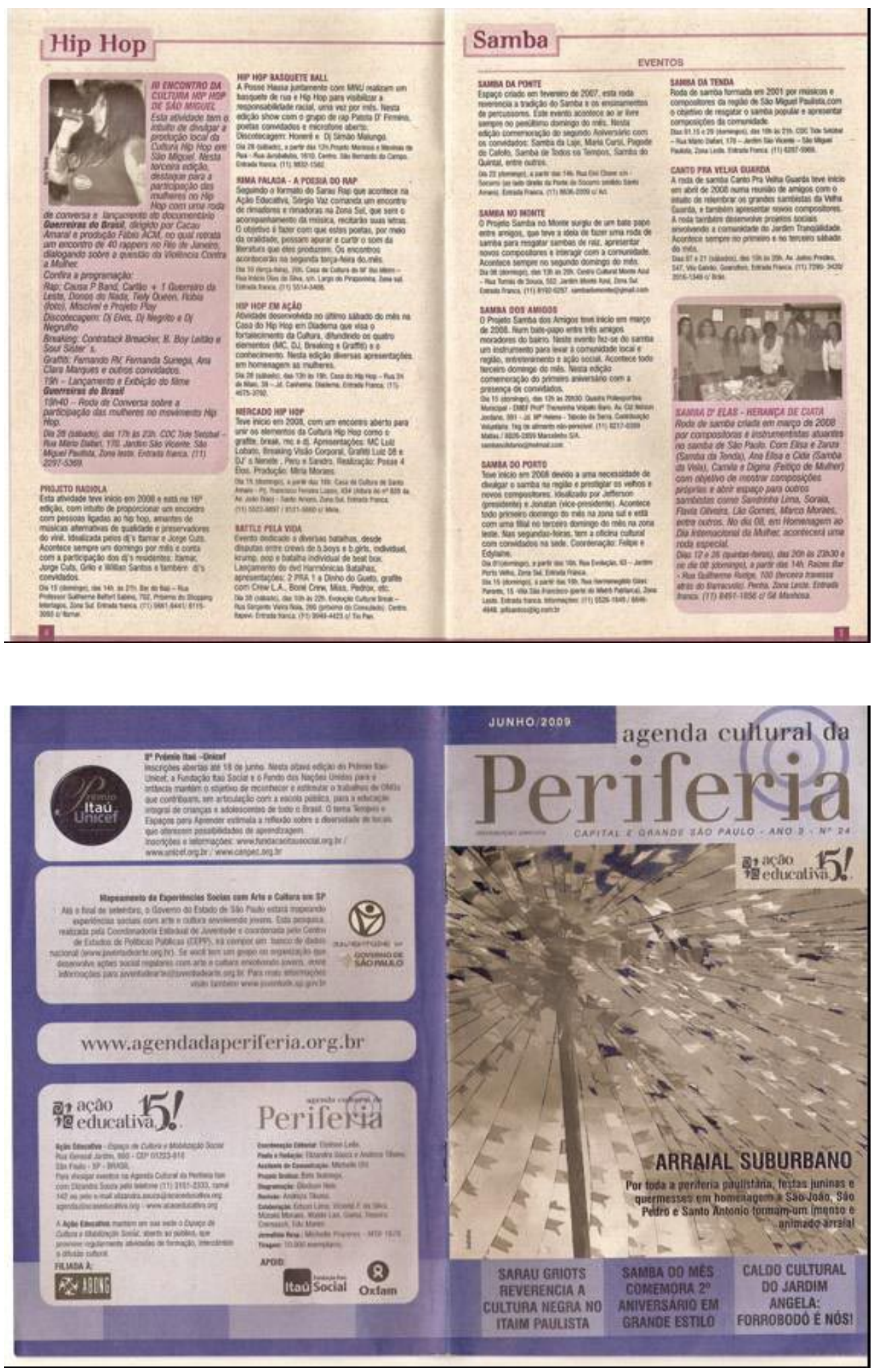

EXTRAPRENSA 
MULHERES NAS COMUNIDADES DE SAMBA TRADICIONAL:

LIDERANÇA E LUTA RESSIGNIFICADAS

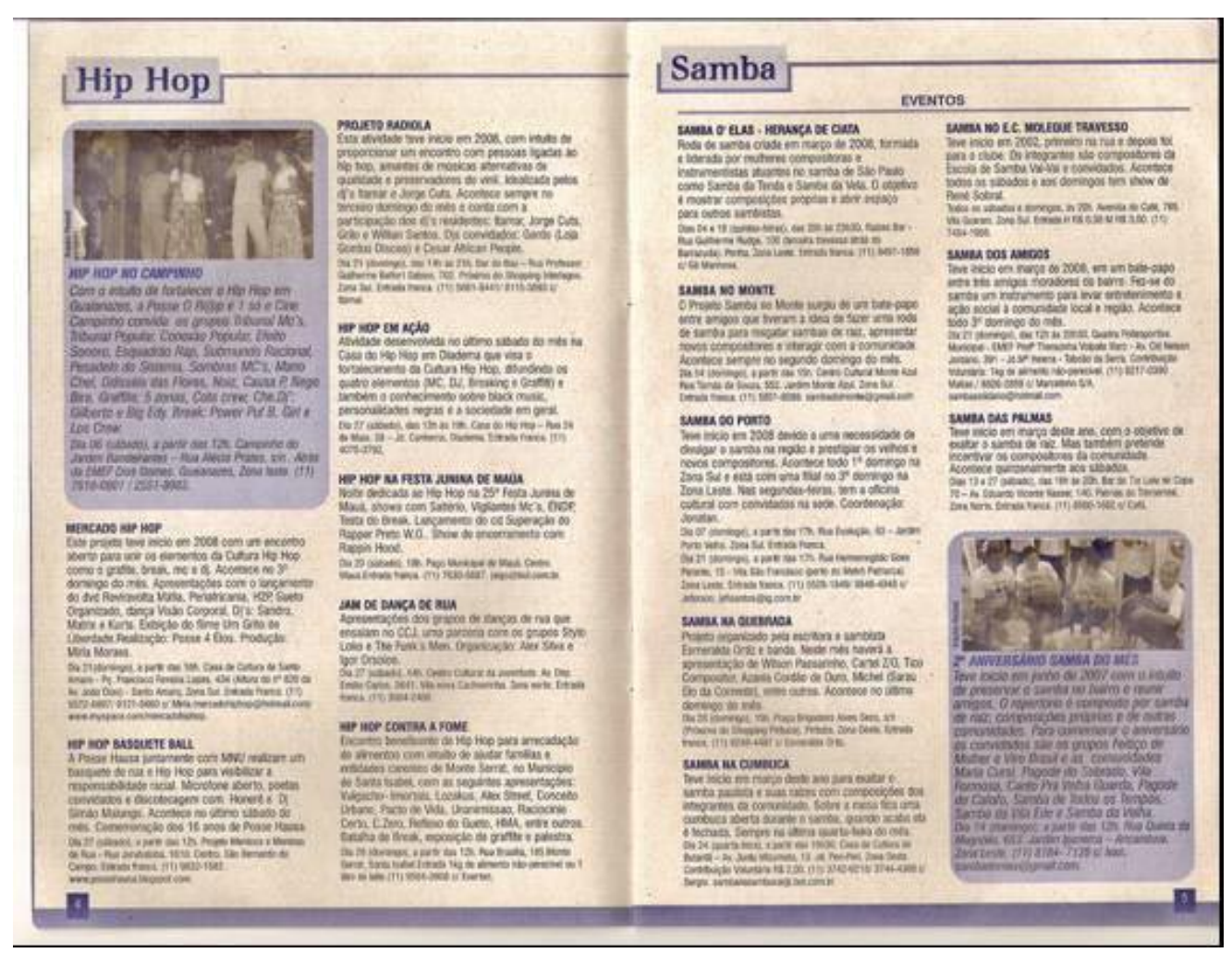

